\title{
The Growth and Stabilization \\ Properties of Fiscal Policy in Malaysia
}


The Growth and Stabilization Properties of Fiscal Policy in Malaysia

Sohrab Rafiq 
This page intentionally left blank

CInternational Monetary Fund. Not for Redistribution 


\title{
IMF Working Paper
}

Fiscal Affairs Department

\section{The Growth and Stabilization Properties of Fiscal Policy in Malaysia}

\author{
Prepared by Sohrab Rafiq ${ }^{1}$
}

Authorized for distribution by Abdelhak Senhadji

June 2013

\section{This Working Paper should not be reported as representing the views of the IMF.}

The views expressed in this Working Paper are those of the author(s) and do not necessarily represent those of the IMF or IMF policy. Working Papers describe research in progress by the author(s) and are published to elicit comments and to further debate.

\begin{abstract}
This paper examines the size of the fiscal multiplier values generated in Malaysia. The results show that a government spending shock leads to broad positive economic effects. Although, the effectiveness of fiscal policy alters across macroeconomic states. The estimates show that since the Asian financial crisis the medium- and long-run effect of fiscal policy spending has declined. Some of this is down to greater credit availability and less investment spending.
\end{abstract}

JEL Classification Numbers: $\quad$ E52, E62, F41

Keywords: Fiscal Policy, Economic Growth, Stabilization, Multipliers, Time-variation Author‘s E-Mail Address: srafiq@imf.org

\footnotetext{
${ }^{1}$ I thank Abdelhak Senhadji, Daniel Leigh, Anke Weber, Joanna Pereira, Phurichai Rungcharoenkitkul, Albert Zeufack, Elif Arbatli, Reem Disu, and Maria Tramuttola for their very helpful comments. In addition to their prepared comments, I also thank seminar participants at the Ministry of Finance in Malaysia. The usual disclaimer applies.
} 


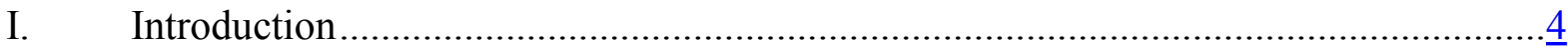

II. Identifying Fiscal Spending Shocks.................................................................

III. Time-Varying Factor Model of the Malaysian Economy .......................................... $\underline{8}$

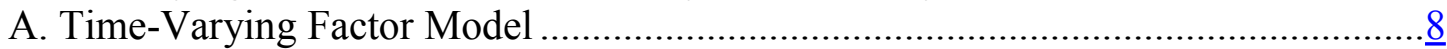

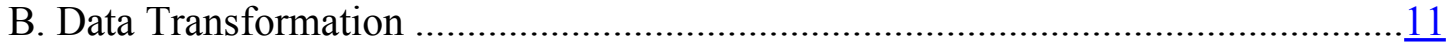

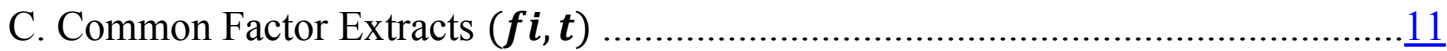

D. Structural Identification of Government Spending Shocks ................................

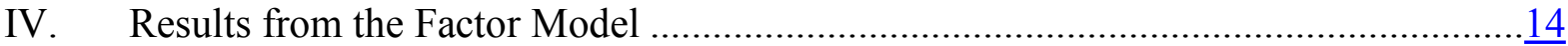

A. Time-Varying Government Spending Shocks and Responses ............................14

B. Real Economic Activity Responses ................................................................ 15

C. Credit Market, Interest Rates, and Money …................................................ $\frac{17}{18}$

D. Trade Balance and the Exchange Rate...........................................................

V. Time-Varying Fiscal Multipliers in Malaysia......................................................19

A. Transmission Channels of Fiscal Policy and Driving Forces of

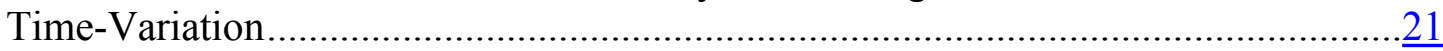

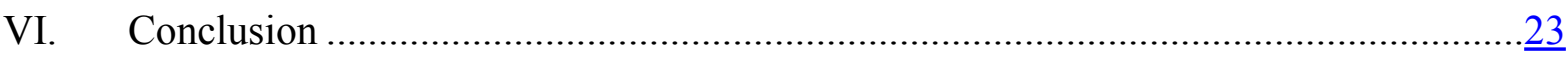

Tables

1. The Cumulative Effect of Fiscal Spending on Output (Annualized) .........................25

2. Determinants of The Spending Multiplier .................................................................

\section{Figures}

1. Government Spending During the Asian Crisis and 2008 Financial Crisis..................

2. Response of Real Economic Activity to a Government Spending Shock Based on a Standard Fixed Coefficient VAR

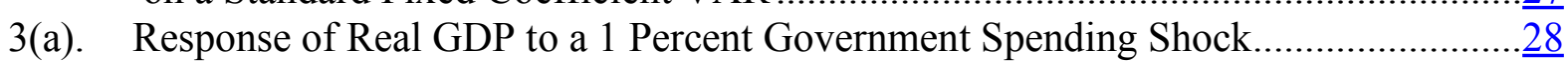

3(b). Response of Private Consumption to a 1 Percent Government Spending Shock ......... $\underline{29}$

3(c). Response of Consumer Sentiment to a 1 Percent Government Spending Shock ......... $\underline{30}$

3(d). Response of Investment to a 1 Percent Government Spending Shock .........................

4. Time-Varying Response of Real Economic Activity to a Government

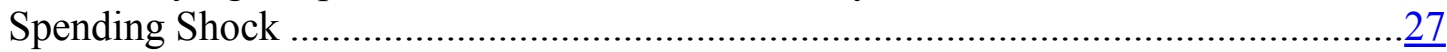

5. Median Response of Economic Sectors to a Fiscal Stimulus ....................................28

6. Median Response of Monetary Aggregates, Credit and Interest Rates to a Fiscal Stimulus .....................................................................29

7. Median Response of Current Account and the Exchange Rate to a Fiscal Stimulus ............................................................................................

8. Time-Varying Median Impact Real GDP Multipliers ......................................... 
9. Time-Varying Median Impact Private Consumption Multipliers $(1988-2010) \ldots \ldots . . .37$

10. Real Output Impact Multiplier and Investment as Percent GDP ..............................

\section{Appendixes}

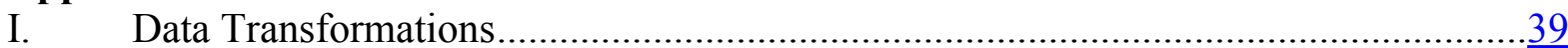

II. Government Spending Shocks ......................................................................

III. Government Spending and Debt in Malaysia ......................................................

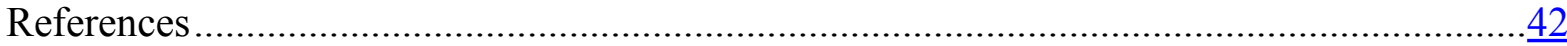




\section{INTRODUCTION}

As well as the habitual undulations in the economic cycle, it is particularly the role of fiscal policy during crisis times that is of relevance to emerging market economies. In investigating this question much of the literature has focused on advanced countries. However, from an analytical standpoint documenting empirical similarities across different levels of development provides an empirical basis for formulating fiscal policies that incorporate relationships that are particularly important for emerging market economies.

\section{Figure 1. Government Spending During the Asian Crisis and 2008 Financial Crisis}
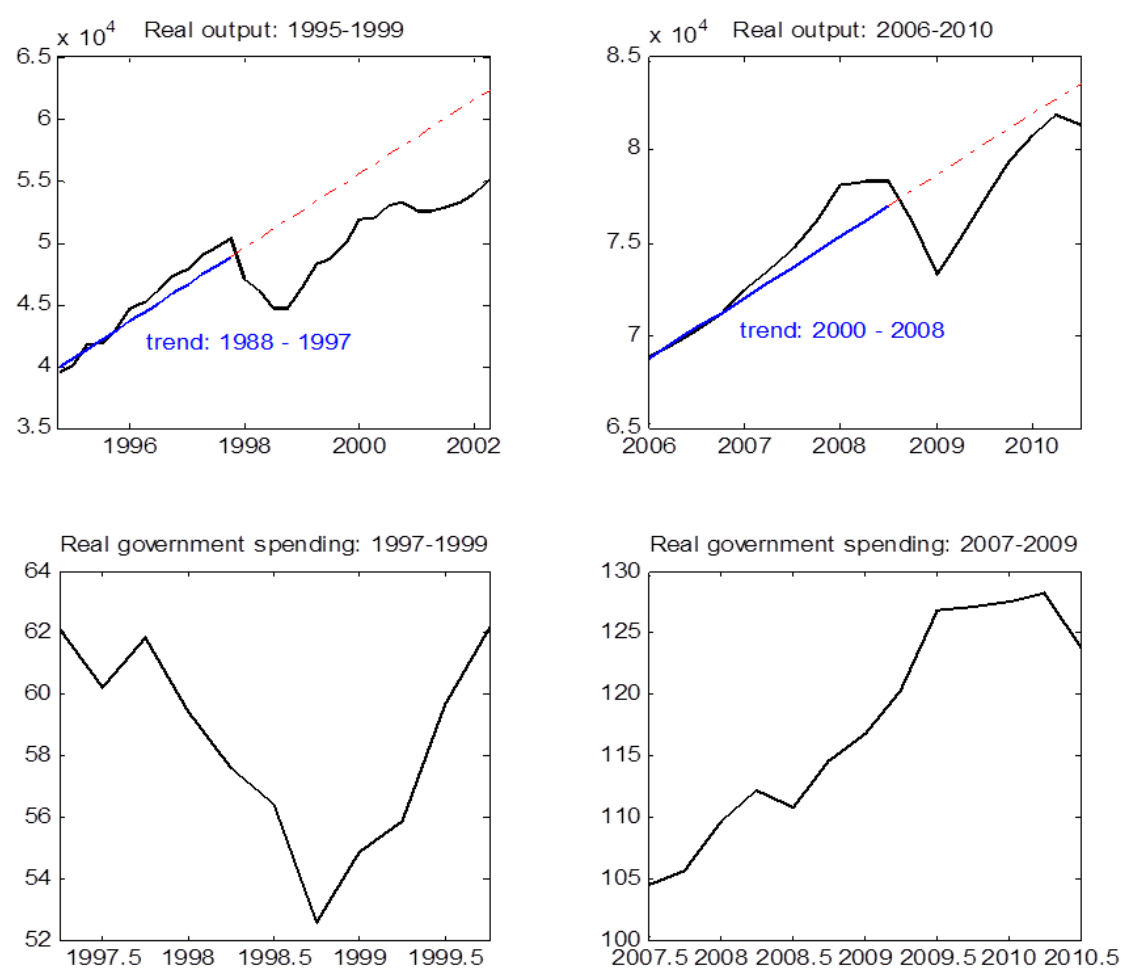

In general, economic fluctuations in emerging economies tend to be more volatile and prone to crisis episodes than those witnessed in OECD countries. If true, as suggested in Blanchard and Summers (1986) of the presence of hysteresis links between the short-run cycle and the long-run trend, then it is central that policies be aimed at preventing L-shaped recoveries. Since the Asian financial crisis in 1997-98, affected economies — including Malaysia - have endured a downward shift in their long run growth trajectory. In contrast to the Asian financial crisis, the 2008-09 world financial crisis provoked a different fiscal policy response, with a large spending stimulus package in Malaysia to counteract the adverse impact on real economic growth. The recovery following the 2008-09 crisis was more V-shaped. With similar patterns having been documented for other countries has led to suggestions that the fiscal multiplier proves to be higher during economic downturns. 
As a result of possible hysteresis effects there has been much discussion on whether contractionary fiscal policies during an economic downturn may be counterproductive. The dialogue is often based in terms of the size of the potential fiscal multiplier. The implication from recent studies suggest that fiscal stimuli during crisis periods can help prevent crises from casting a long-term shadow on future productivity and real output growth. DeLong and Summers (2012) propose that with sufficiently high multiplier values a present-value fiscal expansion would be self-financing in the long run as a result of dampening some of the adverse long-run hysteresis effects that occur on real output as a result of a prolonged economic slump. Aghion, Angeletos, Banerjee, and Manova (2010) show that countercyclical fiscal policy in an emerging market country could play an important role in promoting higher growth and productivity. ${ }^{2}$ The presence of such mechanisms could be particularly useful in boosting the efficacy of fiscal policy in the aftermath of an economic crisis, helping prevent long-term damage to potential output.

Abiad, Balakrishnan, Brooks, Leigh, and Tytell (2009) analyze the medium-term behavior of output on a sample of 88 countries following a banking crises. The paper finds that expansionary fiscal policy (measured as real government consumption) is correlated with higher growth. Similarly, Turrini, Roeger, and Szekely (2011) find that fiscal policy can significantly reduce the impact of financial crises on headline GDP growth, but its impact on potential growth is relatively small. These findings are in line with recent work by Christiano, Eichenbaum, and Rebelo (2009), and Auerbach and Gorodnichenko (2012a,b), which report government spending multipliers to rise during an economic downturn.

Standard macroeconomic models predict the effects of fiscal spending shocks to be small and short lived. This is because it is assumed that fiscal multipliers do not vary much, if at all, across the cycle, making the timing of fiscal consolidation irrelevant. In order to capture multiplier values across the cycle, this paper extracts fiscal multipliers in a novel way by constructing a time-varying model which allows for state dependent fiscal policy effects. This paper estimates an extended - by allowing for changes in the propagation mechanism and shifts in the size of shocks - factor augmented vector autoregression (TVP-FAVAR) model. In contrast to most studies which refer to the typical change in government spending, this paper examines the economy's response to discretionary fiscal policy in normal and extraordinary episodes, such as the Asian financial crisis in 1997.

The inclusion of additional economic information through the use of latent factors should help to arrive at more robust structural estimates, and reduce the risk of misidentification

\footnotetext{
${ }^{2}$ Aghion, Angeletos, Banerjee, and Manova (2010) note that the ability of firms to finance "innovative investment" falls during an economic downturn as a result of a decline in profits. This acts as a constraint on their borrowings. By the government undertaking counter-cyclical fiscal policy, in such circumstances it is possible for fiscal policy to have a positive impact on productivity growth through increasing the demand for goods and services.
} 
compared with low dimensional models. The additional information in the model should also help shed light on some important puzzles that currently exist in the fiscal policy literature. In particular, does private consumption and investment rise or fall in response to a shock in government spending? This issue is implicitly related to the question of whether the noninvertibility problem matters for low-dimensional VAR models tasked with examining the domestic effects of discretionary fiscal policy. Fernandez-Villaverde, Rubio-Ramirez, Sargent and Watson (2007) suggest the use of full information techniques in estimating the structural parameters of models.

Structural changes in the economy, like the process of building up monetary policy credibility, changes in the rules of fiscal policy or productivity improvements in an emerging economies economy - all of which have potentially altered the response of the macroeconomy to the fiscal stance - are progressive in nature. Such change is better captured through the allowance of time-varying coefficients in the factor model. This ensures that smooth transition breaks in the fiscal transmission mechanism are accounted for without imposing a specific breakpoint. The model, therefore, is suited to capturing long-run shifts in the multiplier values. This contrasts with standard nonlinear VAR models which make a distinction between two - usually high frequency expansion and recession—states.

Whilst, the numerical analysis is subject to all the usual caveats concerning model structure this arrives at a number of findings:

- This paper finds that discretionary fiscal stimulus has a significant, but small, shortrun real effect on the economy. There is a small short-term rise in economic activity, reflected by a rise in employment and real economic activity across a broad range of sector and private consumption. A fiscal stimulus also leads to some loosening in private sector credit, increasing broad money growth.

- The time-varying results show that the Asian financial crisis marked the beginning of a large decline in the size of fiscal multipliers in Malaysia. Pre-Asian crisis (19871997) the cumulative real output multiplier was 1.28 after four years. Said differently, an additional ringgit of government spending had added around 1.28 ringgit to real output after four years. The crisis years (1998-1999) saw a fall in the real output impact multiplier value. On average, since the crisis years, an additional ringgit of spending adds around 0.8 sen to real output after four years.

- The decline in the multiplier in Malaysia appears to be due to a combination of factors, namely: increased credit availability, rising imports, and a decline in investment spending in the post-Asian financial crisis era limiting the fiscal effects emanating from the accelerator channel.

The paper is organized into six sections. Section II provides a brief picture in trying to identify the actions of fiscal policy in the literature. Section III sets out a time-varying factor 
model of the Malaysian economy, along with a discussion on the data, model, and structural identification scheme. Sections V and V discuss the results from the model, including the size of the fiscal multipliers. Section VI concludes.

\section{IdENTIFYING FisCAL SPENDING SHOCKS}

The model proposed in this paper attempts to account for a number of modeling critiques aimed at the recent fiscal policy literature, namely; (i) omitted variable bias; (ii) structural shifts in the economy and policy; and (iii) nonlinearities in the relationship between fiscal policy and the economy.

To ensure parsimony standard empirical economic models examining fiscal policy actions employ only a few key variables, typically government spending, real output, and taxes. However, Chari, Kehoe, and McGrattan (2005) have shown that the omission of a state variable from a small dimensional VAR may severely bias the estimated response functions. Missing variables in small dimensional VAR models may lead to an overestimation of the response of output to government spending shocks. For instance, many studies tend to omit a measure of public debt, as well as the stance of monetary policy. However, Auerbach and Gorodnichenko (2012b), and Ilzetzki, Mendoza, and Vegh (2010) find the size of government debt to reduce the response of output to government spending shocks. Models which exclude a monetary policy interaction term may inflate (or deflate) the size of the multipliers, since fiscal spending shocks represent shifts in the IS curve plus any tendency for the monetary authority to shift the LM curve in response.

Small econometric models imply that the information set spanned by the model differs from that exploited by policymakers. ${ }^{3}$ This results in a non-invertibility problem that inflicts low dimensional VAR models. However, Hansen and Sargent (1991) note that more data in the VAR helps solve the non-invertibility problem, and should provide more accurate structural estimates. Using a VAR model augmented with common factors - which synthesize information from a large dataset — helps limit omitted variable bias by increasing the information space spanned by the model.

The inclusion of additional information should help lead to more robust structural estimates. Figure 2 illustrates the impulse response functions of real output for Malaysia based on a simple VAR model of Blanchard and Perotti (2002). The shape of the response functions preand post-Asian financial crisis is different. Additionally, the error bands are wide which suggests significant estimation uncertainty of the effects of government spending shocks on

\footnotetext{
${ }^{3}$ For example, one variable often omitted in the analysis of fiscal policy on the real economy is a measure of household "confidence". Yet, recent work by Bachmann and Sims (2011) highlights the importance of such a variable in the transmission of fiscal policy during economic downturns.
} 
real output. Even the output responses based on estimates across the entire sample demonstrate considerable estimation uncertainty beyond the initial impact stage.

The model in this paper allows for state-dependent fiscal policy effects by not restricting for time variation in the deterministic, autoregressive, and structural parameters. The presence of time-varying parameters accounts for structural shifts that may have occurred in the macroeconomic time series over the last two decades. These shifts could be important, for example, if one wanted to verify the hypothesis that the effect of fiscal policy on economic activity has been similar across episodes.

Finally, recent evidence has also highlighted the asymmetric response of the economy to fiscal policy shifts as a result of whether the country is in boom or depression times. ${ }^{4}$ For example, Tagkalakis (2008) and Auerbach and Gorodnichenko (2012a,b) find that recessions tend to raise the government spending multiplier on real output and private consumption. By allowing for time variation in the autoregressive parameters permits for the possibility of non-linearity in the relationship between economic activity and fiscal policy.

\section{Time-V ARying Factor Model of the Malaysian Economy}

This section lays out the time-varying factor model, along with the structural identification scheme and data transformations.

\section{A. Time-Varying Factor Model}

This is the first paper to examine the role of fiscal policy in a TVP-FAVAR model. This paper uses an extended FAVAR model, by allowing for time variation in the coefficients and stochastic volatility. Equation (1) is an observation equation, where:

$$
\left(\begin{array}{c}
G_{t} \\
Z_{1, t} \\
\cdot \\
Z_{n, t}
\end{array}\right)=\left(\begin{array}{ccc}
1 & 0 & 0 \\
\Lambda^{11} & \Gamma^{11} & \Gamma^{21} \\
\vdots & \vdots & \vdots \\
\Lambda^{1 n} & \Gamma^{1 n} & \Gamma^{2 n}
\end{array}\right)\left(\begin{array}{c}
G_{t} \\
f_{1} \\
f_{2}
\end{array}\right)+\left(\begin{array}{c}
0 \\
u_{1, t} \\
\vdots \\
u_{n, t}
\end{array}\right)
$$

$Z_{i, t}$ is a panel of macroeconomic time series containing information on the current state of the Malaysian economy. The macroeconomic series are linked to the factors through the observation equation (1). It is assumed that $u_{t}$ is uncorrelated with the factors at all leads and lags and is distributed with zero mean, $E\left(u_{i, t} u_{i, t}^{\prime}\right) \sim N\left(0, R_{t}\right)$. The latent factors are denoted

\footnotetext{
${ }^{4}$ See Tagkalakis (2008), and Bachmann and Sims (2011).
} 
$f_{1, t}$ and $f_{2, t}$. The two factors summarize the comovement among the underlying series at each date. The latent factors are derived from the 50 macroeconomic variables. The variable $G_{t}$ is a vector of government spending variables that affect the economy. The factor loading elements are contained in $\Gamma$ and $\Lambda$. The matrices $\Lambda^{1 n}$ determine the contemporaneous interaction between government spending and variable $n$.

Time variation is incorporated into the model by allowing for drift in the coefficients and the stochastic volatilities in a transition equation. The transition equation describes the dynamics of the economy. The time-varying transition equation is expressed in the following form:

$$
y_{t}=a_{0}+b_{1, t} y_{t-1}+\cdots+b_{p, t} y_{t-p}+\varepsilon_{t} \equiv X_{t}^{\prime} \theta_{t}+\varepsilon_{t}
$$

where $y_{t}$ is a vector containing $\left[G_{t}, f_{1, t}, f_{2, t}\right], b_{t}$ is a matrix of $n \times n$ coefficients, and $\varepsilon_{t}$ is a $n \times 1$ vector of unobservable heteroskedastic disturbance terms with zero mean. The vector $\theta_{t}$ is $n(n \cdot p+1)$ in dimension and contains the time-varying VAR reduced-form coefficients, $b_{i, t}$ and the constant term $\left(a_{0, t}\right)$, with $X_{t}=I_{n} \otimes\left[1, y_{t-1}^{\prime}, \ldots, y_{t-p}^{\prime}\right]$. The number of VAR lags in the model is set so $p=2$, while the lag length of the idiosyncratic shocks in the TVP-FAVAR model is also set to $q=2$. Thus, the model is estimated as a TVP$\operatorname{FAVAR}(2,2)$.

It is assumed that the time-varying autoregressive parameters of the transition equation (2), $\theta_{t}=\left\{a_{0}, b_{i, t}\right\}$ evolve as driftless random walks

$$
\theta_{t}=\theta_{t-1}+v_{t}
$$

A stationary prior is imposed on the time-varying reduced-form coefficients

$$
p\left(\theta_{t} \mid \theta_{t-1}, Q\right)=I\left(\theta_{t}\right) f\left(\theta_{t} \mid \theta_{t-1}, Q\right)
$$

where $f\left(\theta_{t} \mid \theta_{t-1}, Q\right)$ characterises the conditional density for the VAR coefficients $\theta_{t}$, $t=1, \ldots, T$. Unstable draws of the reduced form VAR coefficients are rejected according to whether they satisfy the function indicator $I\left(\theta_{t}\right)$. Relaxing the stationarity prior on the VAR coefficients may lead to an overstatement on the amount of time variation.

The $k \times k$ time-variance covariance matrix is decomposed as

$$
\operatorname{VAR}\left(\varepsilon_{t}\right) \equiv \Omega_{\mathrm{t}}=\left(A_{t}^{-1}\right) H_{t}\left(A_{t}^{-1}\right)^{\prime}
$$

The matrix $A_{t}$ is a lower triangular matrix that models the contemporaneous interactions among the endogenous variables and $H_{t}$ is a diagonal matrix which contains the stochastic volatilities, 


$$
A_{t} \equiv\left(\begin{array}{cccc}
1 & 0 & \cdots & 0 \\
a_{21, t} & 1 & \cdots & \vdots \\
\vdots & \vdots & \ddots & \vdots \\
a_{k 1, t} & \cdots & a_{k k-1, t} & 1
\end{array}\right) \quad H_{t} \equiv\left(\begin{array}{cccc}
h_{1, t} & 0 & \cdots & 0 \\
0 & h_{2, t} & \cdots & \vdots \\
\vdots & \vdots & \ddots & \vdots \\
0 & \cdots & 0 & h_{k, t}
\end{array}\right)
$$

with the stochastic volatilities evolving as geometric random walks, independent of one another

$$
\begin{aligned}
& \operatorname{lnh} h_{i, t}=\ln h_{i, t-1}+\eta_{i, t} \\
& a_{t}=a_{t-1}+\xi_{t}
\end{aligned}
$$

The $a_{t}$ structural parameters, which also evolve as driftless random walks, are non-zero and non-one elements of the matrix $A_{t}$ stacked by rows. The coefficients in $A_{t}$ permit for the possibility of nonlinearity and/or time variation in the lag structure of the model.

The law of motion processes of the model and their distributional assumptions are

$$
\begin{aligned}
& \theta_{t}=\theta_{t-1}+v_{t} \\
& a_{t}=a_{t-1}+\xi_{t} \\
& h_{i, t}=\operatorname{lnh}_{i, t-1}+\eta_{i, t}
\end{aligned} \quad\left(\begin{array}{c}
u_{t} \\
\varepsilon_{t} \\
v_{t} \\
\xi_{t} \\
\eta_{t}
\end{array}\right) \sim N\left(0,\left(\begin{array}{ccccc}
R_{t} & 0 & 0 & 0 & 0 \\
0 & \Omega_{t} & 0 & 0 & 0 \\
0 & 0 & Q & 0 & 0 \\
0 & 0 & 0 & S & 0 \\
0 & 0 & 0 & 0 & Z
\end{array}\right)\right)
$$

The assumptions embedded in equations (2)-(8) imply that the dynamics of factor model capture changes in the propagation of structural shocks as a result of shifts in private sector behavior and/or the preferences of law makers who decide fiscal policy. The assumptions in the model account for the possibility of structural breaks in the dynamics that characterize the real economy, as well as changes in the size of shocks buffeting the economy.

The time-varying coefficients are then sampled using the Carter and Kohn (1994) Kalman filter algorithm. The stochastic variances are drawn using the univariate stochastic volatility algorithm of Kim, Shephard and Chib (1998). Estimation is undertaken using Markov Chain Monte Carlo (MCMC) methods. ${ }^{5}$ The posterior estimates are based on a sample of 10,000 draws, obtained by generating 100,000 burn-in draws and then saving every fifth draw from another 50,000 draws. This is enough to ensure that the Gibbs sampler converges, whilst preventing autocorrelation in the Gibbs chain.

\footnotetext{
${ }^{5}$ For reasons of brevity full formulae are not presented here. Instead, direct references to journal articles for more information are provided. Also, see Baumeister, Liu and Mumtaz (2010) for details.
} 


\section{B. Data Transformation}

The model is estimated using quarterly data, which runs from 1987:1 until 2010:3. This period includes two crises (1997 and 2008-09), a change in the exchange rate policy from a floating to a pegged regime (1998-2005), as well as more progressive structural change in the economy partly reflected in the shift away from investment and towards net exports and private consumption for economic growth. The data was collected from a variety of sources (Appendix I). All variables were tested for seasonality and transformed, if necessary, to ensure stationarity.

A combination of stock and flow variables were chosen so as to ensure the diverse range of theories on the fiscal policy transmission mechanism that was nested within the model. These, for example, include variables that capture the level of government debt (Giavazzi and Pagano (1990), Chung and Leeper (2007), Favero and Giavazzi (2007), and Corsetti, Meier and Müller (2012)); asset prices (Corsetti, Meier and Müller( 2012)); trade openness and the current account (Monacelli and Perotti (2007), Kim and Roubini (2008), Ilzetzki, Mendoza and Vegh (2010), and Rafiq (2010)); consumer confidence (Bachmann and Sims (2011)); credit and monetary aggregates (Galí, Lopéz-Solida and Vallés (2007)); the labor market (Pappa (2005)); and real private consumption and investment (Baxter and King (1993), Monacelli and Perotti (2007), and Kim and Roubini (2008)).

\section{Common Factor Extracts $\left(f_{i, t}\right)$}

Stock and Watson (2005) have shown that relatively few factors are needed to capture the common sources of variation amongst a large group of economic time series. The model here is estimated using two common factors - $\mathrm{k}=2$ - extracted from the 50 variable panel dataset. This choice was also in part motivated by Del Negro (2003), which illustrated estimation uncertainty to increase significantly in TVP-VAR models as the number of endogenous variables increase. ${ }^{6}$ The factors are extracted using principal components. ${ }^{7}$

The model does not assign a structural interpretation to the factors. The model aims to investigate heterogeneity in the individual macroeconomic series across sectors to discretionary fiscal spending innovations. Therefore, forcing a proportionality constraint which loads a certain subset of disaggregate series on a particular factor, as in Belviso and Milani (2006), would be overly restrictive. Instead, the dynamics of the variables included in $\mathrm{Z}_{\mathrm{i}, \mathrm{t}}$ are determined by a linear combination of all common factors. Even in the absence of assigning an explicit structural interpretation to the two factors, however, this does not necessarily imply that the latent factors carry no structural interpretation. As documented in

\footnotetext{
${ }^{6}$ The choice of two factors is also consistent with Bai and $\mathrm{Ng}(2002)$.

${ }^{7}$ This ensures all factors have mean zero and variance one. This normalization solves the rotational indeterminacy problem inherent in dynamic factor models by ruling out linear combinations that lead to observationally equivalent models (Baumeister, Liu and Mumtaz, 2010).
} 
Stock and Watson (2005), extracting common factors that are determined as a linear combination of all factors from a large macroeconomic dataset typically results in the first factor capturing changes in real economic activity, while the second factor closely correlates with fluctuations in nominal economic conditions.

\section{Structural Identification of Government Spending Shocks}

There remains substantial disagreement as to how best identify exogenous fiscal policy innovations. Government spending could affect output, while contemporaneously there could be reverse feedback - due to the presence of automatic stabilizers or policy rules. Blanchard and Perotti (2002) ranked government spending before the macroeconomic variables. This minimum-delay assumption implies that in the short run government spending may be unable to adjust to spending in response to changes in fiscal and macroeconomic conditions. Barro and Redlick (2011) argue that a government spending shock in a structural VAR is likely to be endogenous, as higher GDP leads to higher taxes and therefore to more government spending. Barro and Redlick (2011), however, use yearly data. Their argument is unlikely to hold at the quarterly frequency. Realistically, because of decision lags, contemporaneous discretionary government spending is unlikely to respond within a quarter to any news about the economy. This paper follows the convention in the literature by ordering government spending before real economic activity.

The reduced form (transition equation) model (2) is estimated and then a lower-triangular identification restriction - Cholesky factorization - is imposed. The government spending variable is ranked first in the transition equation (2): $y_{t}=\left[G_{t}, f_{1, t}, f_{2, t}\right]$. Equation (1) implies that any contemporaneous correlation between slow moving variables and government spending is accounted for by the loadings contained in $\Lambda$. These assumptions are equivalent to estimating a recursive model, and allowing the factors to respond contemporaneously to government spending. This essentially amounts to removing variables that are not contemporaneously affected by government spending.

As noted previously, factor extracts from a large macroeconomic dataset typically result in the first factor capturing real economic activity. ${ }^{8}$ Therefore, by placing $G_{t}$ before the first factor $f_{1, t}$, the identification scheme is consistent with the multitude of recent studies that place government expenditure before real economic activity. This is based on Blanchard and Perotti's (2002) idea that, due to decision and implementation lags, there is no automatic or discretionary response of government spending to economic activity and other shocks within a quarter.

\footnotetext{
${ }^{8}$ Stock and Watson (2005).
} 
Leeper, Walker and Yang (2009) have shown the presence of fiscal foresight to imply variables not having a VAR representation in the structural shocks. Thus, a true fiscal policy shock and the related impulse response functions cannot be found by estimating a VAR. Realizing that, to some extent, all identification schemes are questionable, does the proposed ordering lead to unpredictable government spending innovations?

Some studies for the U.S. incorporate a measure of private sector forecasts, such as the Survey of Professional Forecasters (SPF), to account for the possibility of any anticipation effects. Such data is unavailable for Malaysia. However, this need not necessarily be problematic. Perotti (2011) has shown that, for the U.S. at least, because the predictive power of expected government spending growth is extremely low the forecast error is almost equivalent to actual spending growth less some noise. For this reason, Perotti (2011) has shown that an expectations augmented VAR can give virtually the same result as estimates from a structural VAR model. As pointed out in Perotti (2005), whether fiscal shocks are truly anticipated or not matters only if anticipated and unanticipated fiscal policy actions have different effects. For a large class of econometric models, Mertens and Ravn (2010) show the probability of a Cholesky decomposition to deliver nearly correct impulse responses even if fiscal policy shocks are anticipated by the private sector is high. From a time-varying perspective even if anticipated fiscal policy might bias the estimated impulse response functions, it is not clear whether and why such effects have changed over time (Perotti, 2005). Since the model in this paper filters out endogenous fiscal policy actions, the extra information incorporated in the TVP-FAVAR model should minimize the risk of misidentification compared to low-dimensional VARs. Additionally, the use of quarterly data to estimate the model in this paper should reduce endogeneity issues that prevail with the use of annual data to identify fiscal shocks.

Finally, following much of the recent literature, to capture the stance of fiscal policy this paper uses government spending $\left(G_{t}\right.$, defined as final real terms spending on goods and services on a cash basis. Typically in the literature government consumption has tended to dominate the analysis. As noted in Corsetti, Meier and Müller (2012), this is also because such a measure of government spending contains little automatic cyclical component, helping to identify government spending shifts beyond those changes due to the economic cycle. Additionally, limited transfer payments in Malaysia imply that final government consumption spending is less likely to be influenced by the presence of automatic stabilizers. Using this definition of government spending also makes the results more comparable with recent literature. ${ }^{9}$

\footnotetext{
${ }^{9}$ The definition of government spending as the purchase of goods and services by the central authority is consistent with the standard national income accounting identification of "G". Also see, amongst many others, Ilzetski, Mendoza and Vegh (2011), Corsetti, Meier and Müller (2012), Gali, Lopéz-Solida and Vallês (2007), Monacelli and Perotti (2007) and Perotti (2005) which use similar measures.
} 


\section{RESUlTS FROM THE FACTOR MODEL}

This section presents and discusses the time-varying response functions derived from the TVP-FAVAR model.

\section{A. Time-Varying Government Spending Shocks and Responses}

In order to calculate the response functions at horizons $t+h$, where $h=1, \ldots, 16$ is the horizon, the posterior distribution of the VAR coefficients is applied for all $t$. This provides a posterior distribution of impulse responses where the responses of all variables to spending shocks hitting the economy at time $t$ are allowed to vary. Given the structural identification scheme the time-varying responses of each underlying variable is calculated using the observation equation

$$
\left(\begin{array}{ccc}
1 & 0 & 0 \\
\Lambda^{11} & \Gamma^{11} & \Gamma^{21} \\
\vdots & \vdots & \vdots \\
\Lambda^{1 \mathrm{n}} & \Gamma^{1 \mathrm{n}} & \Gamma^{2 \mathrm{n}}
\end{array}\right) \times\left(\begin{array}{c}
\mathrm{G}_{\mathrm{t}} \\
\mathrm{f}_{1} \\
\mathrm{f}_{2}
\end{array}\right)
$$

In order to account for parameter drift over the impulse response horizon this paper estimates a nonlinear impulse response function following Koop, Pesaran and Potter (1996)

$$
I R F_{t}=E\left(\theta_{t+h} \mid \Xi_{\mathrm{t}+\mathrm{h}}, \psi\right)-E\left(\theta_{t+h} \mid \Xi_{\mathrm{t}+\mathrm{h}}\right)
$$

where $\Xi$ denotes all the parameters and hyperparameters of the VAR and $h$ is the impulse horizon. The impulse response functions are calculated as the difference between two conditional expectations. The first term in the equation denotes a forecast of the endogenous variables conditioned on a government spending innovation, $\psi$. The second term is the baseline forecast, which is conditional on the government spending shock equalling zero.

To make the responses comparable over time, the government spending innovation is normalised so as to correspond to a 1 percent real terms increase in government expenditure at each date in the sample. The impulse responses are expressed in terms of their deviation from steady state. Since the coefficients are time-varying, the impulse responses are based on parameter values drawn from the posterior at four intervals: 1988:1, 1998:1, 2007:4 and 2010:3. Two of the dates were chosen to highlight the effects of fiscal policy during times of high economic stress. The first date, 1988, is near the start of the sample. The second date represents the period of the Asian financial crisis, which severely impacted Malaysia. The final two dates - 2007 and 2010 — were chosen to highlight any change in the response of the economy to a government spending shock as a result of the recent worldwide financial 
crisis. ${ }^{10}$ The results to a 1 percent government spending innovation are presented in Figures 3 and $7 .^{11}$

\section{B. Real Economic Activity Responses}

In response to a 1 percent shock in government purchases the responses illustrated in Figure 3(a) show a rise in real GDP. Responses drawn in 1987, 2007, and 2010 report a real output increase by around $0.2(0.1)$ percent after six (twelve) months. The responses based on coefficient values drawn during the Asian financial crisis period in 1998 report a 0.2 percent medium- to long-term rise in real GDP. Based on the approximate one-standard deviation error bands, real output responses drawn outside the 1998 Asian financial crisis (1988, 2007, and 2010) demonstrate lower hysteresis.

The rise in real output to a fiscal policy shock over the last 20 years contrasts with Ilzetzki (2011), which reported a statistically significant short- and medium-term decline in real GDP to a government spending shock for Malaysia. The size of the impact of government spending shocks on domestic demand is similar to responses reported in Eskesen (2008) for Singapore (also a country where the government sector plays a larger role in the economy).

The persistent (almost random-walk like) response of real output drawn during the crisis date (1998) is supportive of the idea that a fiscal stimulus at a time depressed economic growth helps prevent a crisis from casting a long-term shadow on real output. In earlier work, Fatas (2000) presented empirical evidence from a large sample of countries showing there to be a correlation between how persistent output fluctuations are and the long-term growth rates of GDP.

Figure 4 illustrates the time-varying responses drawn at each date in the sample of real output to a government spending shock. The time-varying responses show that around the time of the Asian financial crisis (1997-1999) there was a marked rise (fall) in the short-term (longterm) response of real output to a government spending shock. The six-month response jumped from being close to 0 in 1996 to around 0.2 percent by 2000 . In contrast, during the same time span, the 1-year response dropped from around 0.12 to 0.06 percent.

In support of the life-cycle/permanent income hypotheses, the time-varying response of private consumption in Figure 3(b) has been more damped than that of real GDP to a shock

\footnotetext{
${ }^{10}$ The dates were chosen for computational reasons, with some consideration of the reporting results. It is simpler to report complete responses for a handful of dates. Furthermore, with the coefficients gradually changing over time the impulses would not change much from quarter-to-quarter.

${ }^{11}$ The horizontal axis indicates quarters after the shock. The error bands represent the 16 th and 84 th percentile responses from the posterior distribution.
} 
in government purchases. The effect of any fiscal expansion on private consumption has typically dissipated within the first year following the government spending innovation. The small impact of a government spending innovation on private consumption may reflect a high propensity to save among households in Malaysia, which may in part reflect the lack of a comprehensive social safety net. ${ }^{12}$ Additionally, there are significant leakages through trade as well as remittances (nonresident workers form a significant proportion of the labor force), which may weaken the dynamic interrelations between domestic demand components.

That government spending has a minimal long-run positive impact on private consumption and real output for Malaysia is consistent with Kwan (2007), and Rafiq and Zeufack (2012). Again, the exception is the response drawn during the 1998 crisis period, when a fiscal stimulus had a more persistent impact on private consumption. The persistent response of consumer sentiment in 1998 shown in Figure 3(c) is consistent with this finding. ${ }^{13}$ More persistence/permanent movements in consumption and income may reflect shifts in long-run growth. Such shifts tend to be uncorrelated with short-run changes in consumer and business sentiment. Conversely, if fiscal policy contained no news about future fundamentals and the relationship between fiscal policy and subsequent consumption only reflected sentiment, this would be consistent with a transitory response of private consumption to a discretionary fiscal policy spending shock. ${ }^{14}$

There is to-date little consensus on the effects of government spending shocks on investment. The time-varying response functions in Figure 3(d) show that investment was at its most sensitive to government purchase shocks during the Asian financial crisis period of 1997-98. Responses drawn outside these dates observe a small short-term (six-month) positive effect on real investment following a government spending shock. The short lived initial rise is similar to results reported for the U.S. in Burnside, Eichenbaum and Fisher (2003). There is little evidence of a persistent accelerator effect from the rise in domestic demand. The fall in investment in the medium term is a result documented in other studies, including Blanchard and Perotti (2002) for the U.S., and Corsetti, Meier and Müller (2012) for the OECD. If public spending does not lead to a rise in the marginal productivity of private factor inputs, private investment will less likely be crowded in, inducing low multiplier values.

Chakraborty and Dabla-Norris (2011) show that relatively small micro-level productivity effects of public capital can generate large macro-level effects. Azrai and Zeufack (2011) have documented a decline in total factor productivity in Malaysia post-Asian crisis.

\footnotetext{
${ }^{12}$ Household saving rates are currently over 30 percent in Malaysia.

${ }^{13}$ Such effects are often prescribed to Keynes' animal spirits. The relationship between confidence and real economic activity reflects empirical measures of confidence and are reflective of changes in future economic fundamentals, particularly long-run trend shifts. Also see Cochrane (1994).

${ }^{14}$ See Bachmann and Sims (2011) and Cochrane (1994).
} 
Figure 5 shows the response of different economic sectors to a fiscal expansion. A shock in government purchases has diffuse real economic effects. The estimates show that a fiscal stimulus leads to a broad economy-wide increase in growth. The rise in economic activity leads to a short-run six month increase in capacity utilization with firm bankruptcies also declining. These findings are consistent with the idea that a fiscal stimulus pushes out the demand curve of goods and services for firms.

\section{Credit Market, Interest Rates, and Money}

Figure 6 reports the responses of various monetary aggregates and interest rates to a fiscal policy shock. The responses for narrow money (M1) based on coefficient values drawn either side of the Asian financial crisis (1987, 2007, and 2010) report an initial rise followed by an absolute decline after six months. A positive fiscal policy impulse eventually led to some monetary tightening in the short- to medium-term. In contrast, narrow money rises persistently for the response based on coefficient values in 1998. This implies little monetary offset by the authorities to a spending shock during the Asian financial crisis years, and some alignment between monetary and fiscal policies.

The rise in private consumption (Figure 3(b)) and broad money aggregates (M2 and M3) is consistent with the expansion in (nominal) domestic credit. Despite the looser stance of monetary policy, the increase in domestic credit to a fiscal expansion was slightly more dampened for the response drawn in 1998 compared to the expansion in domestic credit during non-crisis times. This probably reflects the adverse conditions faced by the domestic banking system during this time. These results are suggestive of the view that expansionary fiscal policy eases liquidity constraints in normal, and may help alleviate them during crisis times.

The effect of a fiscal expansion on the perceived credit risk in the economy - the Ted spread - increases (albeit by a very small amount) for six months for those responses drawn during relatively normal times $(1987,2007,2010)$. It must be noted that the majority of domestic public debt in Malaysia is held by the domestic banking sector. In contrast, the Asian crisis response (1998) reports a decline in the Ted spread and the money market rate. ${ }^{15}$

The rise in the Ted spread may also reflect a steepening in the term spread. The expectations channel in a liquidity trap environment assumes that an effective economic recovery should lead to a rise in expected real output, inflation and future short-term interest rates and, hence, long-term rates (the so-called neo-Wicksellian view). The short-term steepening in the term

\footnotetext{
${ }^{15}$ Ait-Sahalia, Andritzky, Jobst, Nowak, Tamirisa (2012) found announcements concerning fiscal stimulus packages during a financial crisis to be unassociated with significant reductions in interbank risk premia.
} 
spread coupled with a rise in economic activity would be consistent with improved economic optimism.

A steepening in the yield curve would be consistent with the expansion in private sector credit. The mechanism between the yield curve and banks balance sheets may be rationalized as follows: since loans offered by banks tend to be of longer maturity than the liabilities that fund those loans, the term spread is indicative of the marginal profitability of an extra dollar of loans on intermediaries' balance sheet (Adrian, Estrella and Shin, 2010). Banks' balance sheets grow as a result. In the monetary policy literature these series of events have been coined the "risk-taking" channel of monetary policy. The decline in firm bankruptcies (see Figure 5) coupled with an increase in private sector credit is consistent with the idea that a fiscal stimulus could help alleviate a rise in financial market frictions.

\section{Trade Balance and the Exchange Rate}

Figure 7 shows a fiscal expansion to deteriorate the current account position, which is consistent with the notion of twin deficits. ${ }^{16}$ This result reflects the fact that the rise in domestic demand precipitates higher real imports, which act as a leakage in any fiscal policy. ${ }^{17}$ It may also be noted that exports from Malaysia have a high import content.

What could explain the depreciation in the exchange rate in the face of an expansion in aggregate demand? The negative comovement between consumption, the current account balance, and the REER represents one of the puzzles of open economy macroeconomics. It is difficult to fit any definitive story to the response of the real exchange rate given thesometimes large - interventions by the monetary authorities that take place on the foreign exchange market. Although, the weakening in the exchange rate in response to a fiscal expansion should act to boost the size of the multiplier values.

Open economy macro models based on the Mundell-Fleming framework show fiscal multipliers to be greater under a more fixed exchange rate regime since monetary policy is more accommodating to a fiscal expansion than under a more independent monetary policy

\footnotetext{
${ }^{16}$ Theoretically, a rise in government purchases boosts domestic aggregate demand and entails a rise in the domestic interest rate. This causes a nominal (and real) appreciation and in turn a deterioration of the trade balance. Fiscal policy can also affect the current account by altering the relative price of nontradables. A fiscal expansion that leads to an increase in the consumption of nontradables could induce a real appreciation, which in turn may tilt private consumption toward tradables. However, there is little evidence of a REER appreciation. Additionally, a fiscal expansion that boosts domestic demand and interest rates in the short term can attract capital inflows, which may also worsen the current account.

${ }^{17}$ It must be noted that modern intertemporal models of the current account imply that large current account imbalances — or large deviations from sustainability — should not be persistent through time.
} 
regime. ${ }^{18}$ Finally, there is little evidence of overshooting. This is consistent with assumptions contained in the Dornbusch-Mundell-Fleming model, which predicts no exchange rate overshooting in response to real shocks, including fiscal ones. ${ }^{19}$

\section{Time-VARYing Fiscal Multipliers in Malaysia}

Based on the derived impulse responses from a fiscal shock it is possible to calculate the size of the fiscal multiplier. The real output and private consumption multiplier value calculations are based on the dynamic impulse response functions of real output and government spending. Such a measure accounts for changes in the persistence of the government spending shock. The more persistent a budget deficit is expected to be, the more likely it is that current individuals will not be around before taxes are raised, and therefore the larger is the wealth effect and the multiplier. On the other hand, Monacelli and Perotti (2007) showed in a New Keynesian dynamic general equilibrium model with perfect foresight that more persistent positive government spending shocks lead to a fall in real output. Figures 8 and 9 report the time-varying impact fiscal multipliers for real output and real private consumption over the entire sample period..$^{20}$ As a note of caution, however, focusing on the very shortterm impact may be misleading since fiscal stimulus packages can only be implemented over time and there may be lags in the economy's response. ${ }^{21}$

The time-varying estimates show considerable variation in the size of the impact fiscal multiplier over the last two decades. In general, fiscal multipliers in Malaysia have been smaller than stipulated by traditional Keynesian analysis over this time. The one-to-four year impact multipliers rose during the early 1990s before reaching a plateau in the mid-1990s of around 0.45. The time-variation shows that the Asian financial crisis in 1997-8 marked the beginning of a large adjustment in the size of short- and long-term impact fiscal multipliers for real output and real private consumption. The size of the one-to-four year real output multipliers fell in the latter part of 1998. The peak impact multiplier pre-1997 was around 0.45 compared to approximately 0.16 post-Asian crisis. The small long-run (four year) multiplier value post-Asian crisis is consistent with neoclassical predictions which imply

\footnotetext{
${ }^{18}$ See Ilzetzki, Mendoza and Vegh (2011), which reports empirical evidence showing fiscal multiplier values to be higher under more controlled exchange rate regimes. The standard IS-LM framework hypothesis that a fiscal expansion in a floating exchange rate environment leads to a monetary policy tightening induced by higher economic growth, reducing the fiscal multiplier value.

${ }^{19}$ See Devereux and Purvis (1990).

${ }^{20}$ The 3D-graphs of the time-varying relationship graphs are to be read in the following way: along the $\mathrm{x}$-axis the starting quarters are aligned from 1988Q1 to 2010Q3; on the y-axis the quarters after the fiscal policy shift are displayed; and on the $\mathrm{z}$-axis the value of the real output response to a change in government goods and services purchases.

${ }^{21}$ See Ilzetzki, Mendoza and Vegh (2011).
} 
demand shocks are neutral in the long run, as well as being inconsistent with economic growth theories based on the idea of self-financing. ${ }^{22}$ The decline in the impact multiplier value mirrors the fall in the response of real output to a government spending shock illustrated in Figure 4.

In contrast to the dynamics of the impact multiplier at horizons of one year and above, the effectiveness of government spending at short-horizons (less than one year) post-Asian crisis has risen. The very short-term (six month) multiplier has risen post-1997 from around 0.4-0.5 to $0.7-0.8$. This supports the notion that a government spending shock is fast impacting on real economic activity, suggesting the usefulness of discretionary fiscal policy for short-run stabilization purposes. The rise in the short-run multiplier would lean toward a gradual fiscal adjustment. With larger short-term multipliers a gradual spending adjustment will have a smaller negative impact on output in the short term than a front loaded reduction. With government debt levels rising (see Appendix III) some consolidation may be on the horizon.

The range of spending multiplier values estimated from the model are within the range of results reported in recent literature. Ilzetzki (2011) estimated a short-run multiplier of 0.17 and a long-run multiplier of 0.15 for a group of developing countries, which included Malaysia. Using the IMF's Global Integrated Monetary and Fiscal (GIMF) model, Freedman, Laxton and Kumhof (2008) reported a one-year multiplier of 0.7 for government investment spending in emerging Asia. Using a fixed coefficient VAR model Eskesen (2008) report an impact multiplier of around 0.25 for Singapore. Estimating a similar model, Hur (2007) reports most fiscal multipliers for South Korea to be strikingly small with only transient real effects. These studies, however, tend to omit a measure of public debt, and an interest rate term. Such omissions may lead to an overestimating of the size of the multiplier values. The impact multipliers are also in line with those reported in Estavão and Samake (2013), which reported a cumulative multiplier of between 0 and 0.3 for a group of emerging market countries in Central America.

The multiplier values are smaller than those reported in Rafiq and Zeufack (2012) for Malaysia. Rafiq and Zeufack (2012) reported a peak multiplier value of around 2 during recessionary episodes, and a negative multiplier value in expansionary times to a shock in government consumption spending. Nonlinear VAR models, as utilized in Rafiq and Zeufack (2012) or Auerbach Gorodnichenko (2012a,b), tasked with measuring fiscal multipliers across regimes tend to assume that the parameters in the two states-growth and expansion-are constant. However, if there is a positive probability of the economy shifting from a recessionary to an expansionary phase in future periods, then the multipliers starting in recession (or expansion) should be a mix of those estimated for the separate regimes. Without accounting for such a change in circumstances such models may exaggerate the size

\footnotetext{
${ }^{22}$ See Aghion, Angeletos, Banerjee and Manova (2010).
} 
of the multiplier value. However, the model in this paper has the advantage of being able to measure multiplier values that are a mix of two (or more) states.

What may explain the rise in the short run (six month) response of real GDP to a government spending shock at short horizons, is shown in Figures 4 and 8. Appendix II illustrates there to have a change in the profile of a government spending shock. The time path of the rise in the persistence of a government spending shock in Appendix II follows a similar pattern to the increase in the response of real GDP illustrated in Figures 4 and 8. The rise in the short-run persistence of a government shock over the sample may offer a partial explanation for the rise (decline) in the short- (long-) run multiplier illustrated in Figure $8 .{ }^{23}$ In models which allow for the presence of Ricardian agents, as in Galí, López and Vallés (2007), the impact of government spending on consumption and output is can be inversely related to the persistence of the shock. Given the large changes that have occurred in the multiplier values are the different horizons it may be more instructive to look at the cumulative multiplier figures. The cumulative government spending multiplier value, calculated by adding up the point multiplier value at year one-to-four, is reported in Table 1.

The pre-Asian financial crisis estimates show that it took around three years for the spending outlay to be recouped through a higher level of GDP. After four years the cumulative spending multiplier was 1.28. In contrast, the cumulative post-Asian financial crisis multipliers show that after four years the cumulative spending multiplier was around 0.85 . The estimates also show that post-Asian crisis private consumption is almost completely crowded out after four years to a government spending shock. ${ }^{24}$ The real output multiplier is similar to that reported in Eskesen (2008) for Singapore, which reported a real output fouryear cumulative multiplier of around 0.8 to a government spending shock. The cumulative long-run real output multiplier value is, however, much larger than the analogous figure reported for a group of 10 developing countries - including Malaysia — in Ilzetzki, Mendoza and Vegh (2011), which reported a median cumulative figure of 0.18 over a 20 -year sample period.

\section{A. Transmission Channels of Fiscal Policy and Driving Forces of Time-Variation}

This section examines possible explanations for the decline in the long-run fiscal multiplier. This is achieved by regressing the one-year median multiplier values for output and private consumption on plausible determinants of multiplier values. However, as noted in Canova and Pappa (2006), and Cimadomo, Hauptmeier and Kirchner (2010), since the fiscal

\footnotetext{
${ }^{23}$ Another possible reason for the increase in the short-term multiplier, as suggested by the Ministry of Finance of Malaysia, is improvements in the institutional capability to implement fiscal stimulus in dealing with external shocks since the Asian financial crisis.

${ }^{24}$ This also implies that public and private consumption may not be complimented.
} 
multipliers are themselves estimates from generated regressors, running a standard ordinary least squares regression may bias the coefficient estimates. To help overcome such biases a Bayesian regression is estimated. The coefficients and standard errors are based on estimates drawn from 100,000 draws of the posterior distribution of the dependent variables using a Gibbs sampler. ${ }^{25}$

The independent variables are chosen so as to test key hypotheses in the literature that are thought to determine the size of fiscal multipliers. ${ }^{26}$ To address the possibility of reverse causation from spending lagged values of the independent variables are used. Additionally, in order to counter any possible spurious causation trend and constant terms are included. The point estimates of the regression coefficients are the means of their posterior distribution. The statistical significance of the regression coefficients is measured in terms of the posterior probability that they are non-positive (non-negative) if their point estimates are positive (negative). The results are reported in Table 2.

The signs of the size of the estimated coefficients in the four regressions are by and large analogous even accounting for the inclusion and subtracting of additional variables. The estimates are consistent with textbooks of economic theory. A rise in credit is associated with a fall in the real output multiplier. The negative coefficient value is consistent with Galí, López and Vallés (2007), which showed that as the fraction of "rule of thumb" (ROT) consumers - characterized by their inability to borrow — rises, government spending shocks will have more of an impact on economic activity. This finding is consistent with the positive coefficient value on the financial market stress variable - measured as the spread between the corporate bond rate (BAA) and the (supposedly risk neutral) domestic (three month) treasury bill rate.

The regression estimates also show that a rise in imports leads to a decline in the real output multiplier. The decline in the real output multiplier is of the order 0.001-0.022. This is consistent with standard Keynesian theory, which predicts a higher fiscal multiplier in more closed economies. The small coefficient values could be the result of the high import content of exported goods from Malaysia.

Based on the size of the coefficient values, the results imply the most effective way of raising the size of the multiplier values is with government spending which crowds in investment. This finding is in line with results reported in Rafiq and Zeufack (2012), which showed a larger real output multiplier in response to government investment spending. Table 1 shows that a 1 percentage point rise in the real investment-to-GDP raises the one-year impact real

\footnotetext{
${ }^{25}$ See Koop (2003) and Canova and Pappa (2006).

${ }^{26}$ See Corsetti, Meier and Müller (2010) and Cimadomo, Hauptmeier and Kirchner (2010) for a literature review.
} 
output fiscal multiplier by approximately 0.35 at conventional significance levels. ${ }^{27}$ Interestingly, the sign of the debt coefficient becomes positive once investment is included in the equation.

The time-varying relationship between investment and the fiscal multiplier values at a twoto-four year horizon is illustrated in Figure 10. In contrast to multiplier values at horizons less than a year, the estimates show that the impact multipliers at one-year horizons and greater have been closely correlated with investment over the last 15 years. Leeper, Walker and Yang (2009) have shown how government spending linked to investment tends to be more effective in the longer term. This may help explain the closer correlation between the longer term multipliers and investment than for short-term multiplier values. A scatter plot between GFCF investment and the size of the multiplier value illustrates a statistically significant positive relationship. A key legacy of the Asian financial crisis in Malaysia (as well as in some other countries affected by the crisis) was the drop in investment and its failure to recover back to pre-crisis levels. Azrai and Zeufack (2011) note the decline in investment in Malaysia to almost entirely reflect a reduction in private sector investment. ${ }^{28}$ If public spending fails to raise the marginal productivity of private factor inputs, private investment will less likely be crowded in, inducing low multiplier values.

The historically close relationship between total investment and the size of fiscal multipliers infers, first, that there may be complimentarities between different components of spending and, second, that the effectiveness of fiscal policy could be improved if it focused on factors that improve the returns to investment. Public investment can provide a context which raises the returns to private investment. One way in which private sector returns could be raised is through a rise in public investment which may, in turn, revive private investment if complementarities exist. The results in this paper imply that, for an emerging market country like Malaysia, a reduction in investment as a result of an economic downturn may also cast a shadow on the size of the multiplier.

\section{Conclusion}

For normative and positive reasons, Malaysia's macroeconomic history provides a unique and interesting study on the effects of fiscal policy on the real economy in a middle-income emerging market country. Given the country's history with financial crises, changes in exchange rate policy and long-term structural shifts in the economy that have turned the

\footnotetext{
${ }^{27}$ The result in Table 2 implies that when the investment ratio is higher ex-ante (namely, one period before), the fiscal multiplier is larger.

${ }^{28}$ Also see Park, Shin and Jongwanich (2009), which documented large falls in investment for countries affected by the Asian financial crisis.
} 
country from a low into a middle-income country, this paper investigates the role of different economic environments in shaping the fiscal transmission mechanism.

The numerical analysis in this paper is subject to all the usual caveats concerning the assumptions on structural identification, lag length and choice of priors. A logical extension of this paper would be to examine whether there has been a similar decline in the size of fiscal multipliers for the other Asian economies that were severely affected by the Asian financial crisis and, if so, the primary cause. 
Table 1. The Cumulative Effect of Fiscal Spending on Output (Annualized)

\begin{tabular}{lcccc}
\hline \hline & $\begin{array}{c}\text { Average Real Output Multiplier } \\
\text { Pre-Asian } \\
\text { Crisis }\end{array}$ & Post-Asian Crisis & Pre-Asian Crisis & Post-Asian Crisis \\
\cline { 2 - 3 } & 0.28 & 0.37 & 0.15 & 0.02 \\
Year 1 & 0.59 & 0.48 & 0.31 & 0.02 \\
Year 2 & 0.92 & 0.66 & 0.49 & 0.01 \\
Year 3 & 1.28 & 0.85 & 0.67 & 0.01 \\
\hline \hline
\end{tabular}

Note: The accumulated figures are calculated as in Spilimbergo, Symansky and Schindler (2009). 
Table 2. Determinants of The Spending Multiplier ${ }^{\mathrm{a}, \mathrm{b}, \mathrm{c}}$

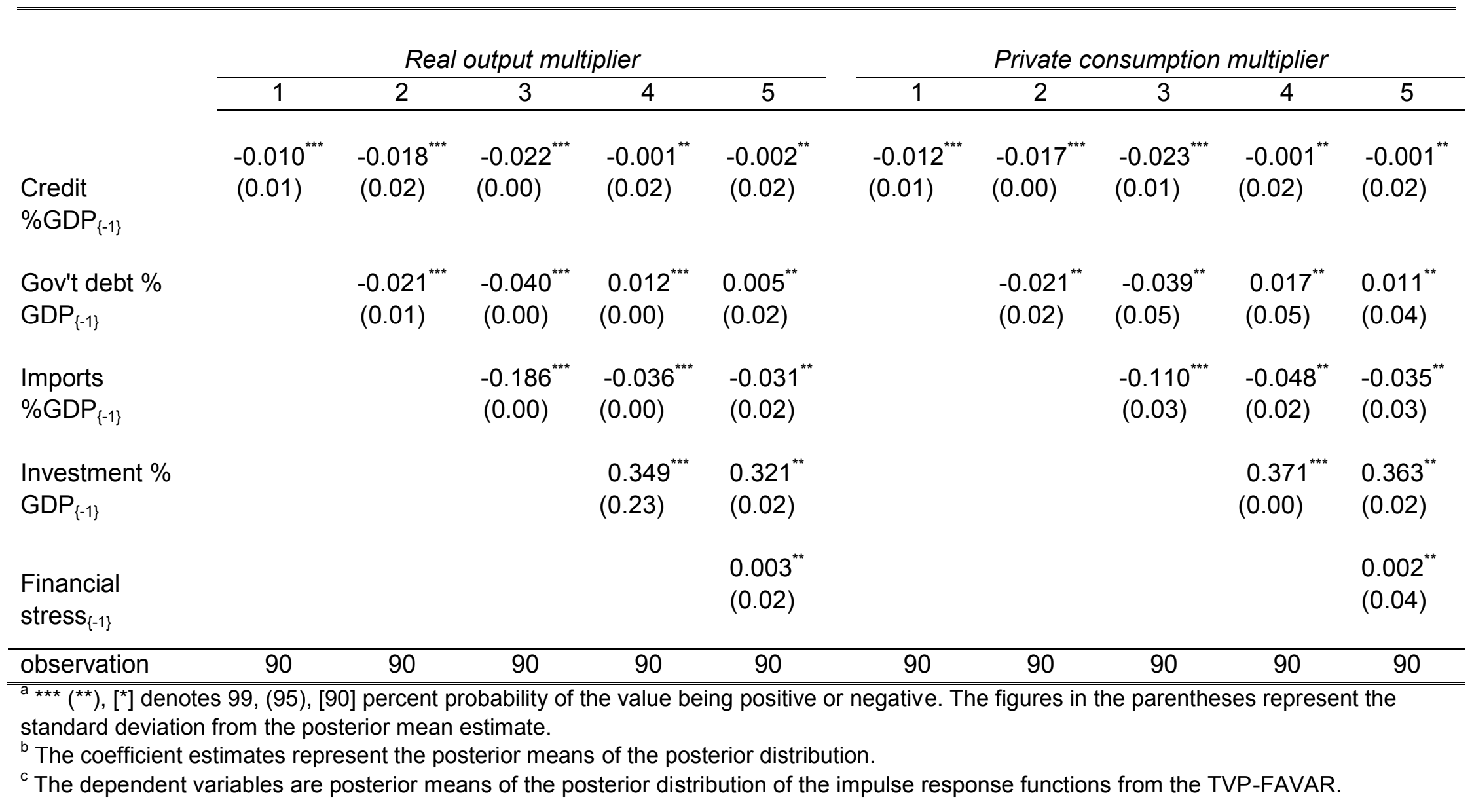


Figure 2. Response of Real Economic Activity to a Government Spending Shock Based on a Standard Fixed Coefficient VAR ${ }^{29}$
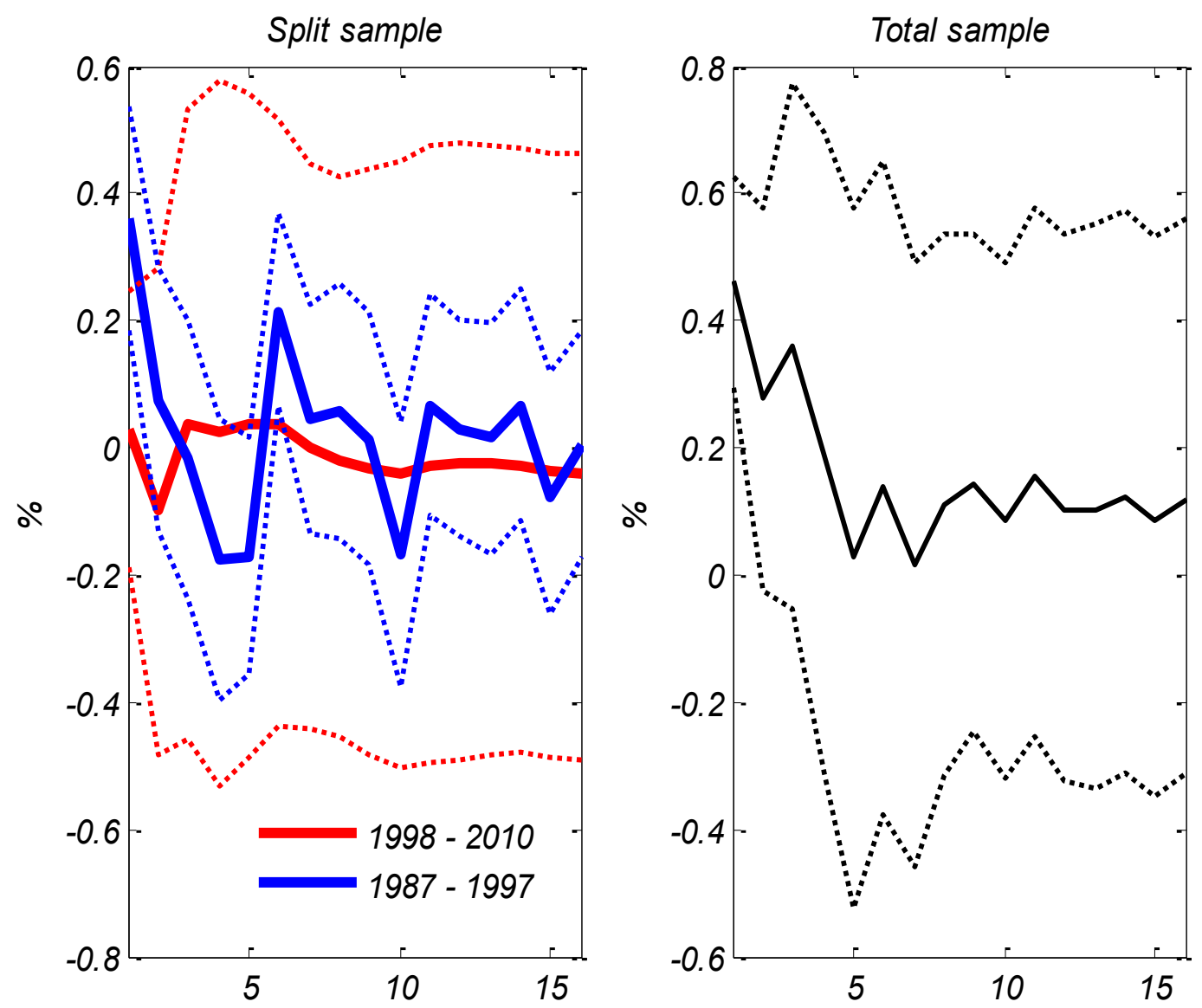

Note: Author's projections and estimates.

\footnotetext{
${ }^{29}$ The model is estimated with four lags and using the identification scheme outlined in Blanchard and Perotti
} (2002). 
Figure 3(a). Response of Real GDP to a 1 Percent Government Spending Shock
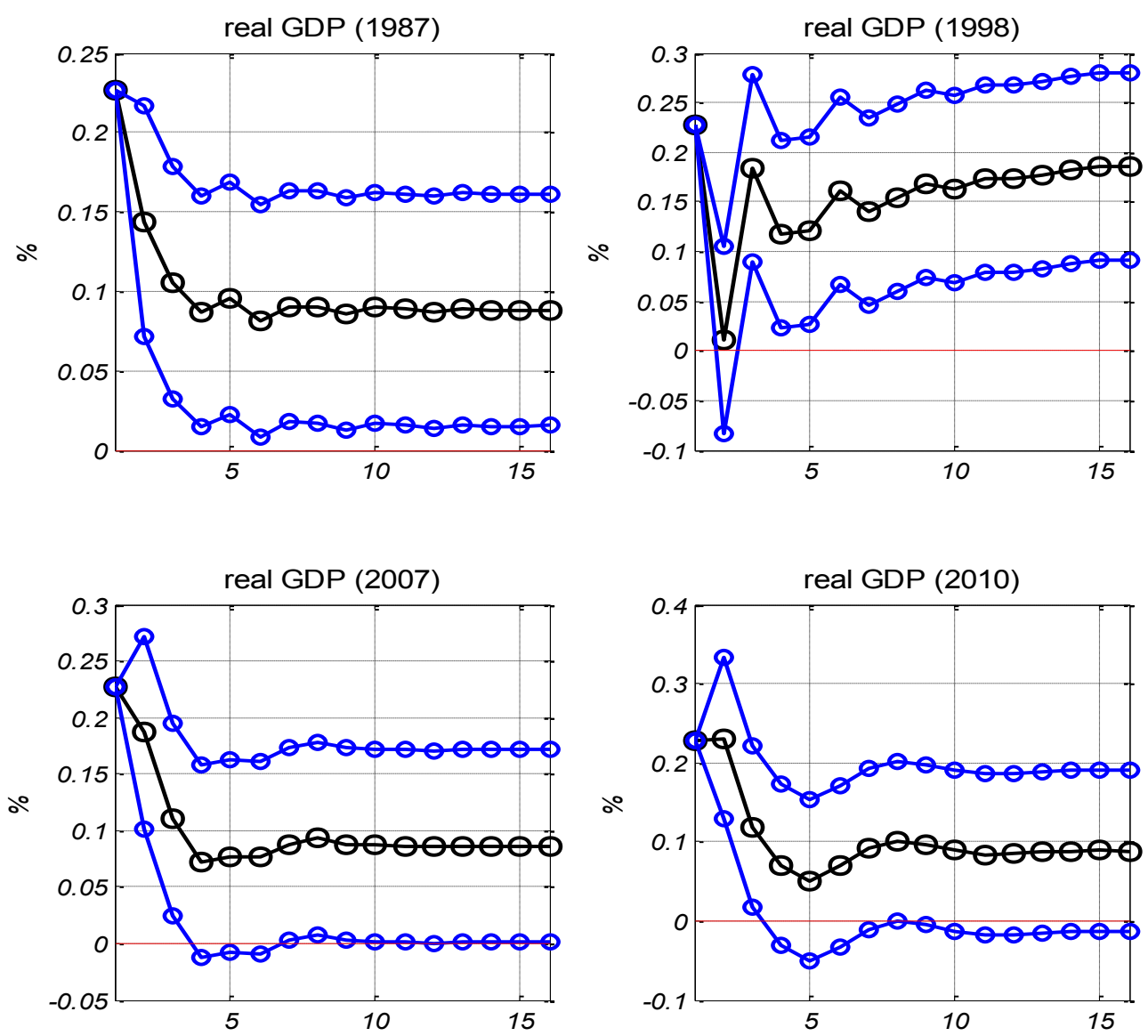

Note: Author's projections and estimates. 
Figure 3(b). Response of Private Consumption to a 1 Percent Government Spending Shock
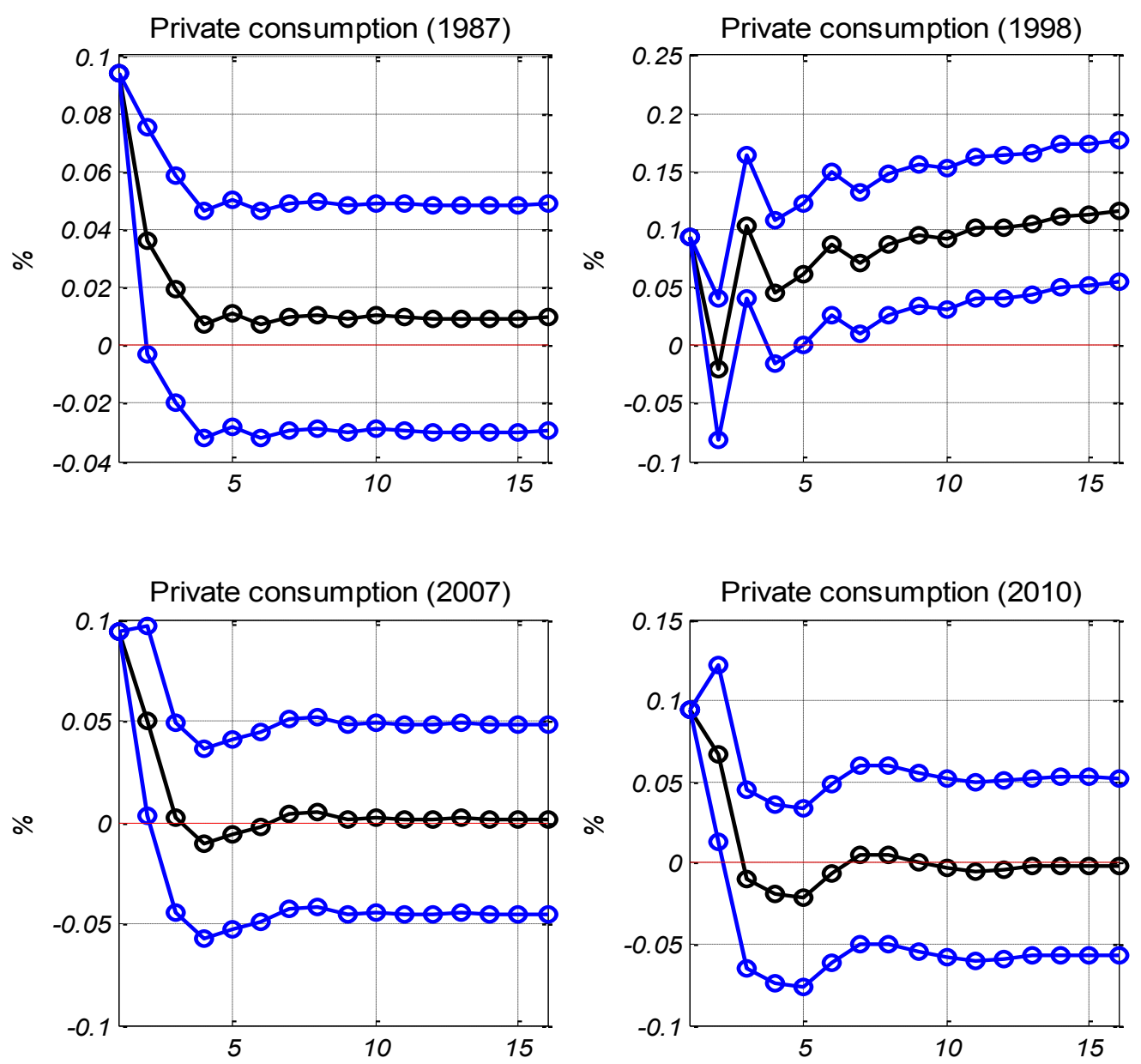

Note: Author's projections and estimates. 
Figure 3(c). Response of Consumer Sentiment to a 1 Percent Government Spending Shock
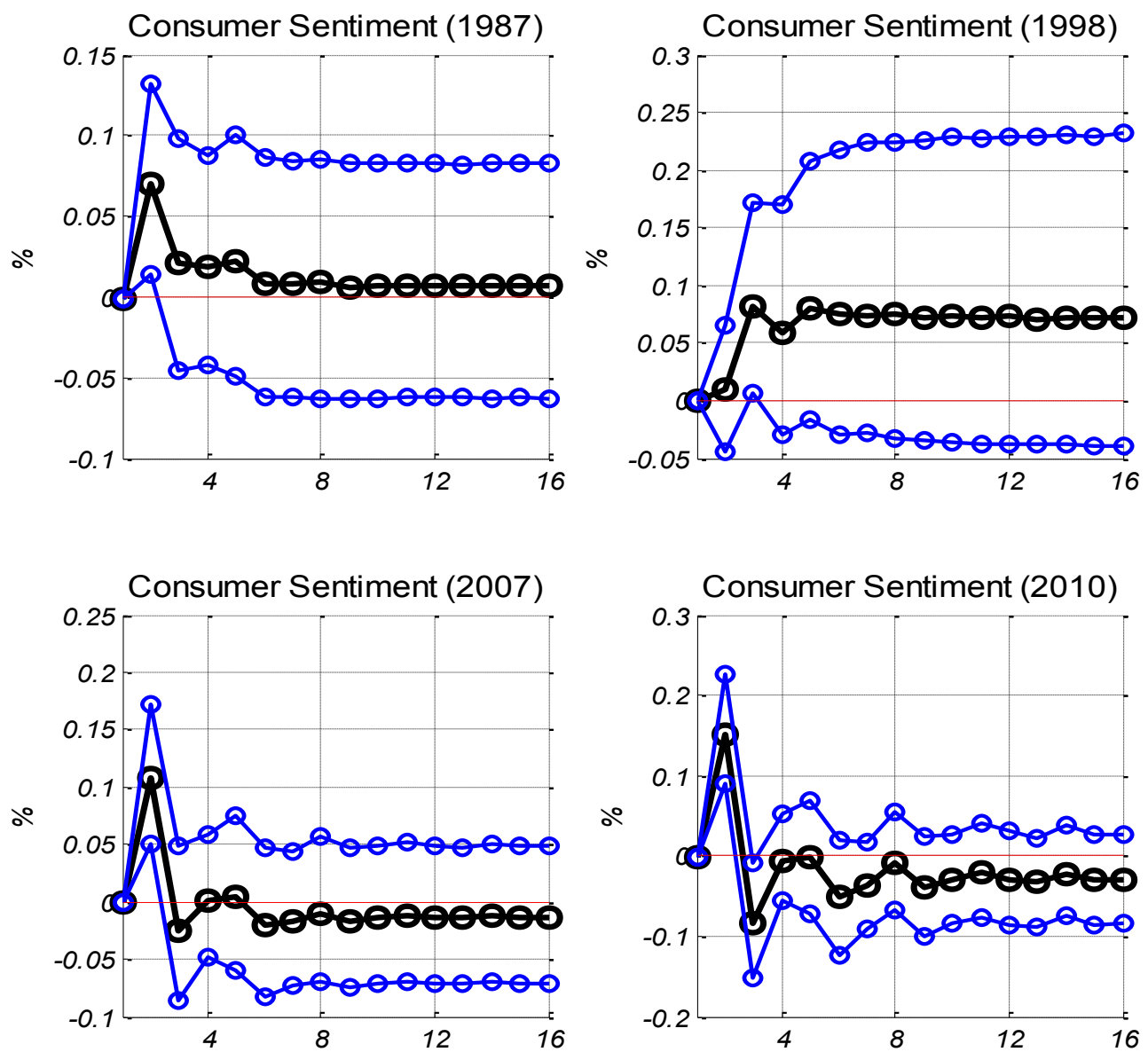

Note: Author's projections and estimates. 
Figure 3(d). Response of Investment to a 1 Percent Government Spending Shock
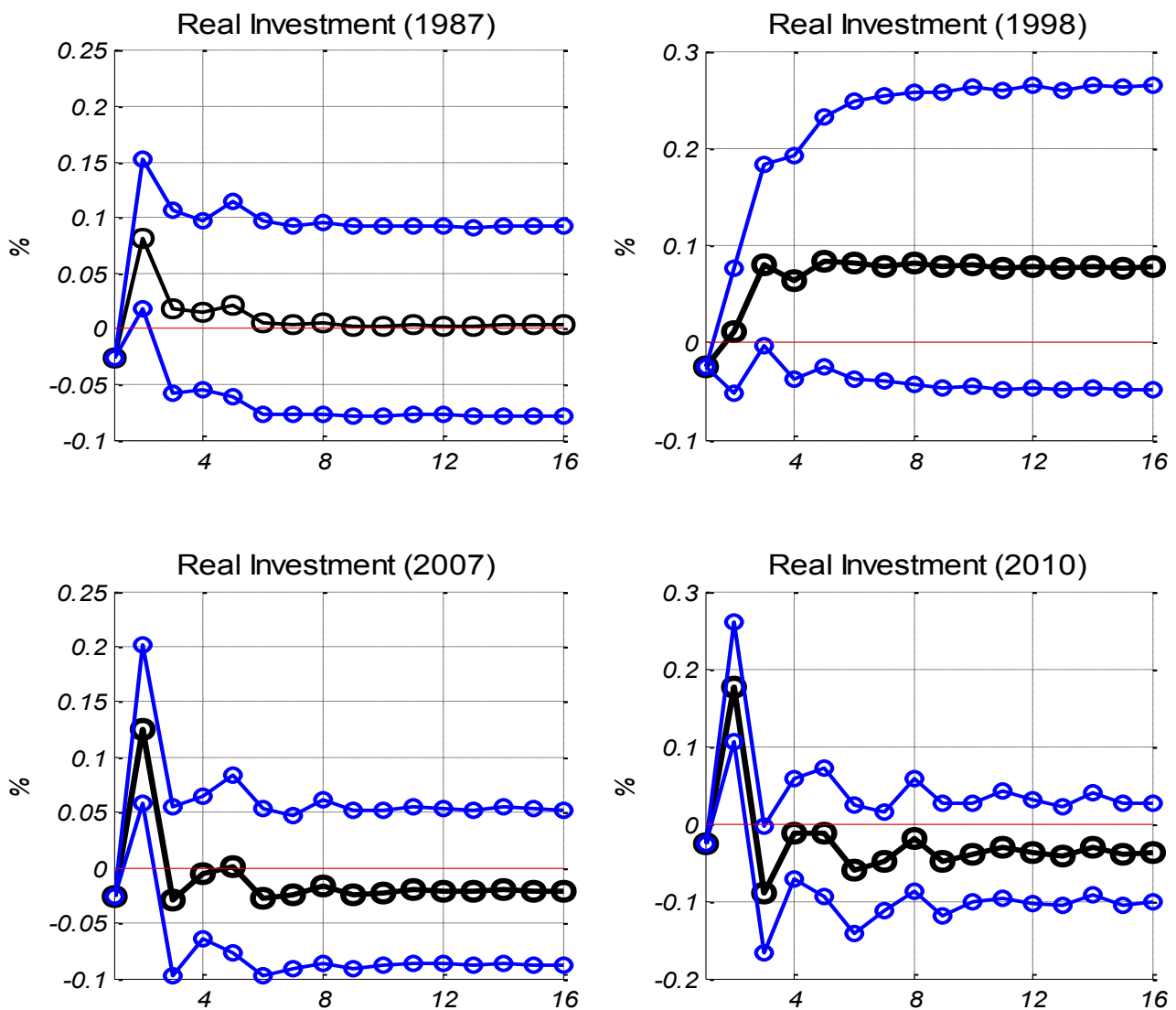

Note: Author's projections and estimates. 
Figure 4. Time-Varying Response of Real Economic Activity to a Government Spending Shock
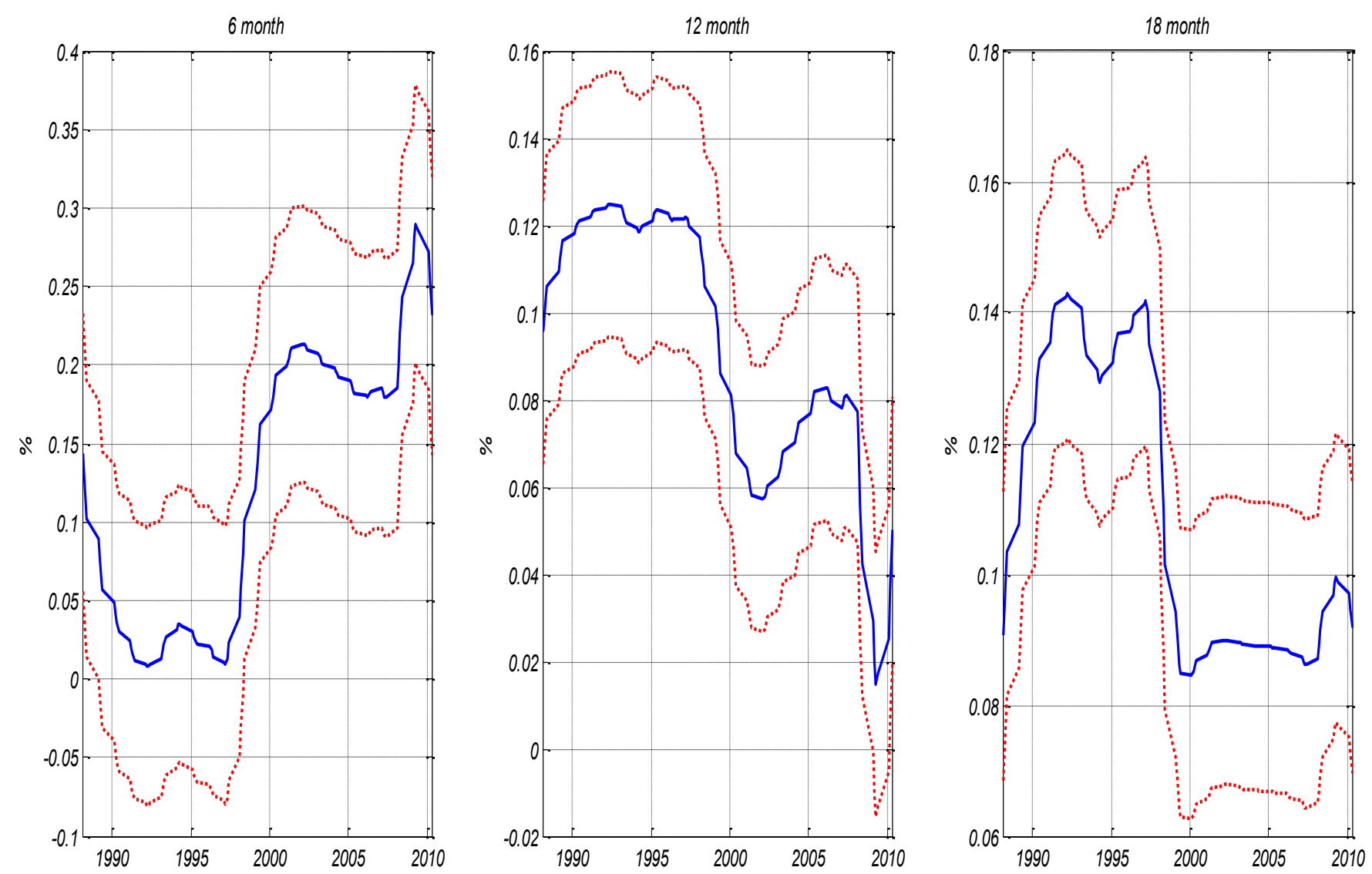

Note: Author's projections and estimates. 
Figure 5. Median Response of Economic Sectors to a Fiscal Stimulus

(1987, 1998, 2007, 2010)
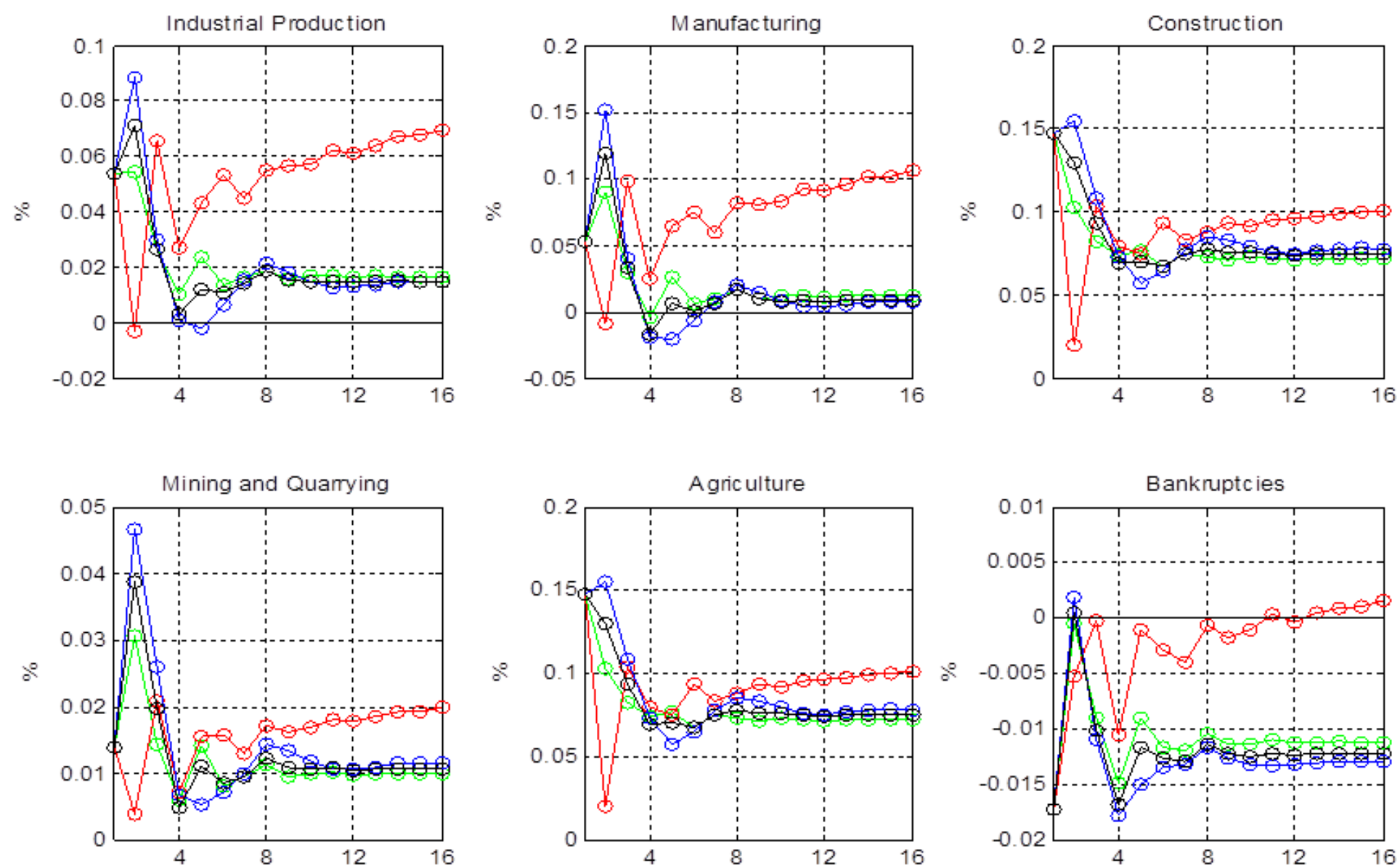

Note: Author's projections and estimates. 
Figure 6. Median Response of Monetary Aggregates, Credit and Interest Rates to a Fiscal Stimulus (1987, 1998, 2007, 2010)
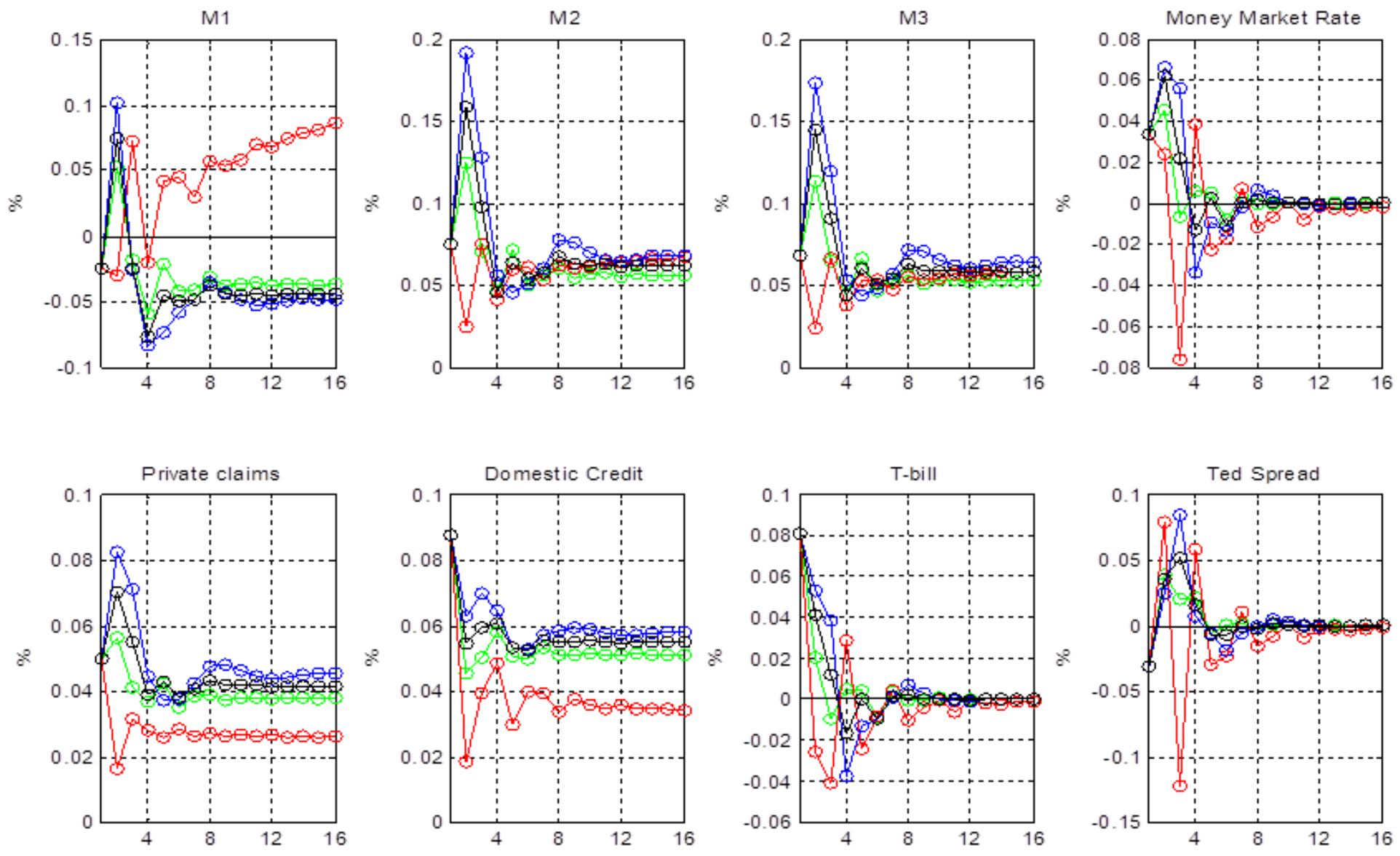

Note: Author's projections and estimates. 
Figure 7. Median Response of Current Account and the Exchange Rate to a Fiscal Stimulus (1987, 1998, 2007, 2010)
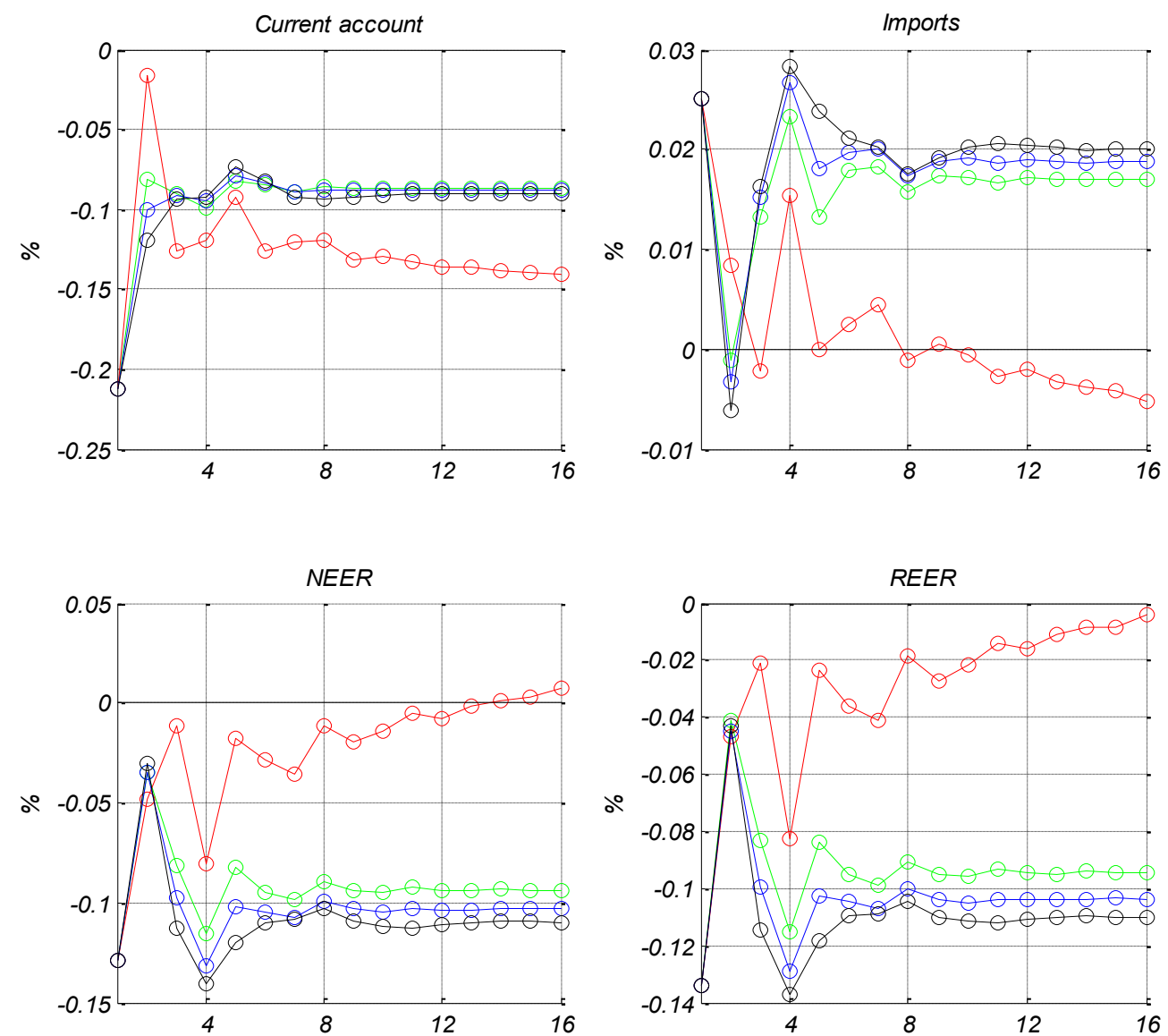

Note: Author's projections and estimates. 
Figure 8. Time-Varying Median Impact Real GDP Multipliers

(1988- 2010)

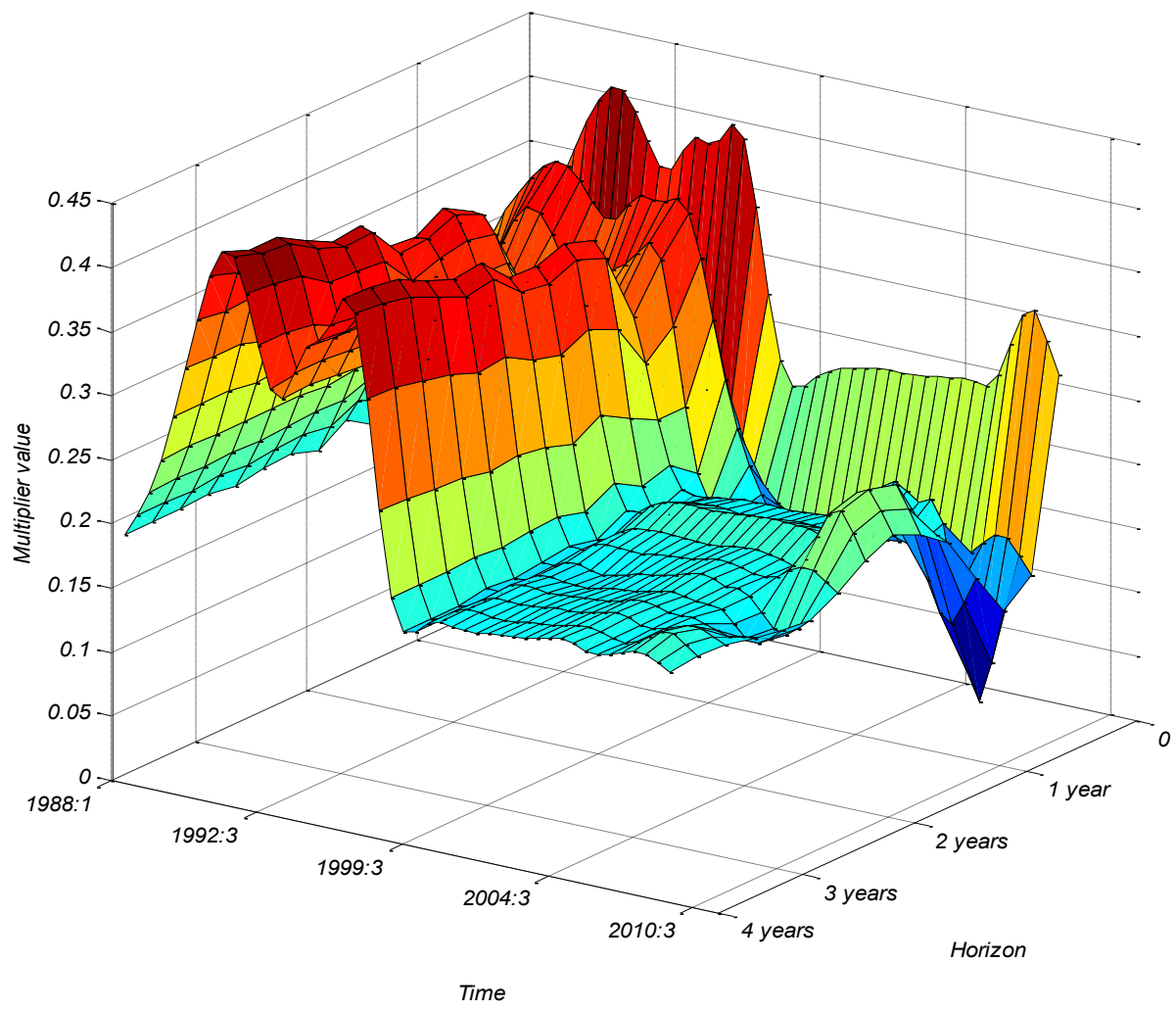

Note: Author's projections and estimates. 
Figure 9. Time-Varying Median Impact Private Consumption Multipliers (1988 - 2010)

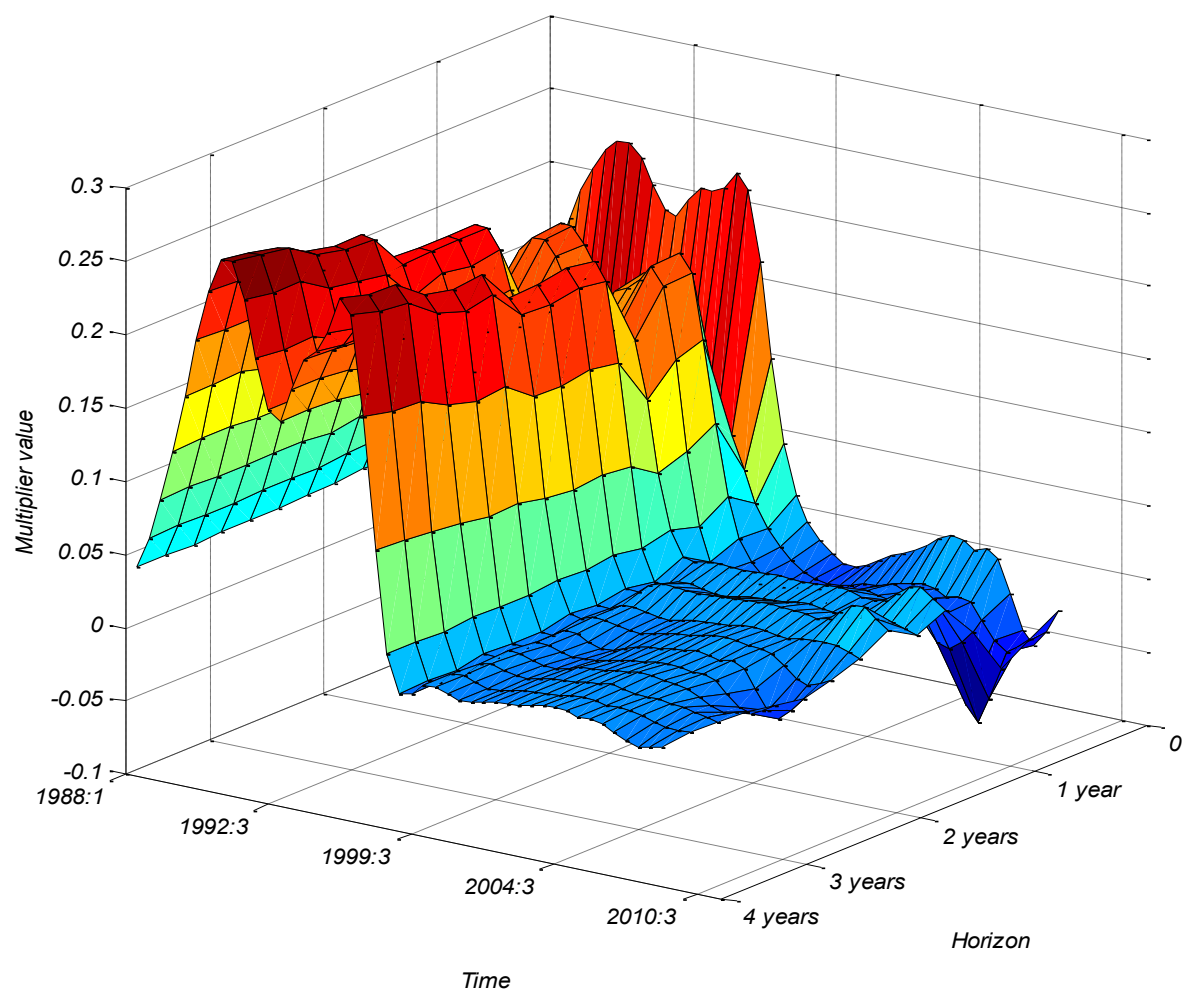

Note: Author's projections and estimates. 
Figure 10. Real Output Impact Multiplier (-) and Investment (GFCF) as Percent of GDP ( $($ )
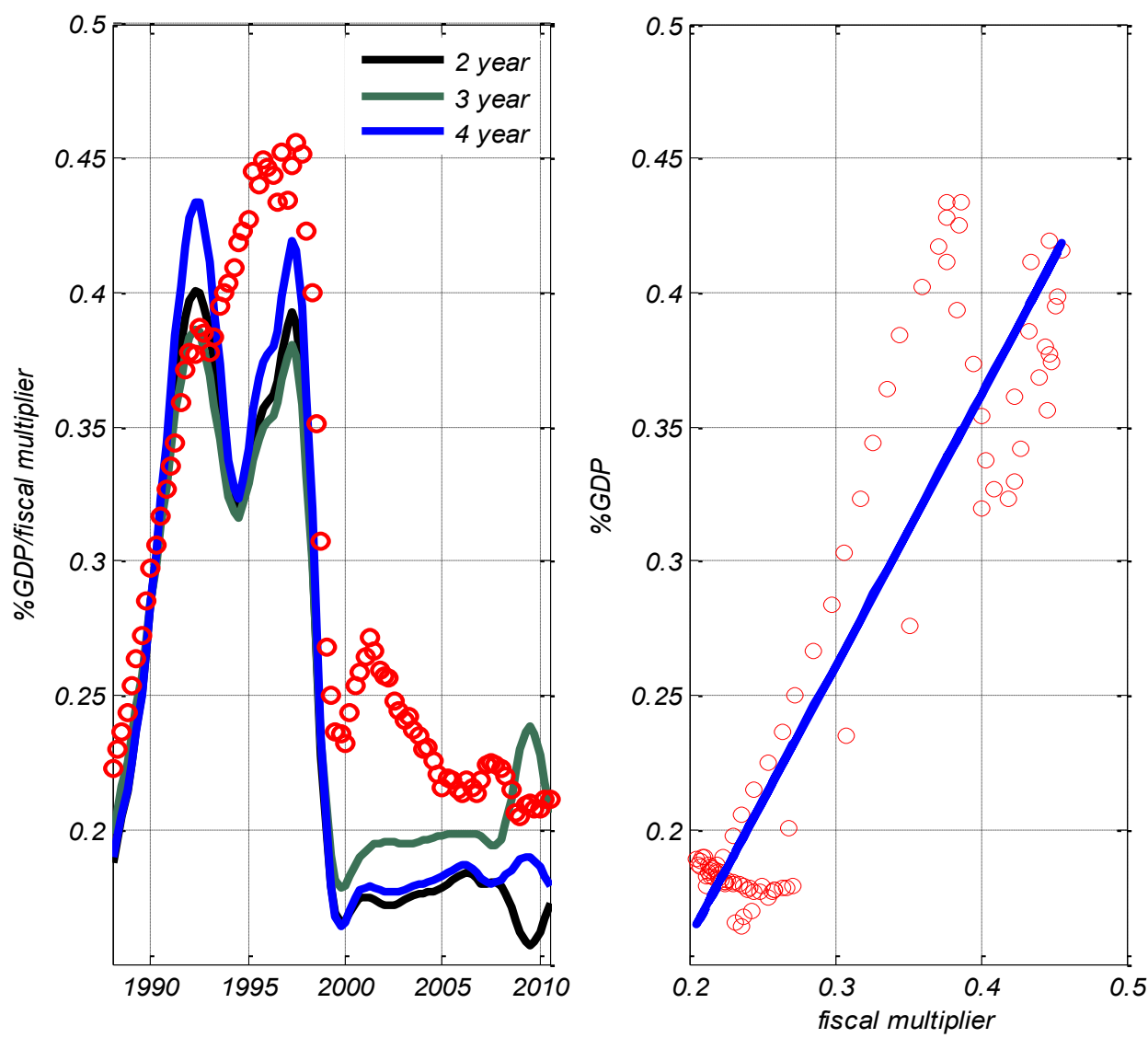

Note: Author's projections and estimates. 
APPENDIX I. DATA TRANSFORMATIONS

\begin{tabular}{|c|c|c|}
\hline \multicolumn{3}{|c|}{ Macroeconomic Data: 1987:1-2010:3 } \\
\hline Variable & Source & Transformation \\
\hline Real GDP & Abeysinghe and Gulasekaran (2004) & 3 \\
\hline Private consumption & CEIC & 3 \\
\hline Investment (as proxied by GFCF) & CEIC & 3 \\
\hline Exports (f.o.b) & CEIC & 3 \\
\hline Imports (c.i.b) & CEIC & 3 \\
\hline Industrial production & CEIC & 3 \\
\hline Manufacturing & CEIC & 3 \\
\hline Agriculture & CEIC & 3 \\
\hline Mining and quarrying & CEIC & 3 \\
\hline Construction & CEIC & 3 \\
\hline Capacity utilization & Malaysian Inst. Econ. Research & 3 \\
\hline Bankruptcies & CEIC & 3 \\
\hline Consumer sentiment & Malaysian Inst. Econ. Research & 3 \\
\hline Current account balance & CEIC & 3 \\
\hline Employment index & Malaysian Inst. Econ. Research & 3 \\
\hline Unemployment rate & Malaysian Inst. Econ. Research & 3 \\
\hline Domestic credit & CEIC & 3 \\
\hline Private claims (depository institutions) & CEIC & 3 \\
\hline M1 & CEIC & 3 \\
\hline M2 & CEIC & 3 \\
\hline M3 & CEIC & 3 \\
\hline Reserve money & CEIC & 3 \\
\hline Money market rate & CEIC & 1 \\
\hline Savings rate & IMF IFS & 1 \\
\hline Deposit rate & IMF IFS & 1 \\
\hline Treasury bill rate & CEIC & 1 \\
\hline Ted spread (interbank-Tbill rate) & CEIC & 1 \\
\hline $\begin{array}{l}\text { Interest rate difference (Tbill—U.S. Tbill } \\
\text { rate) }\end{array}$ & CEIC & 1 \\
\hline Share price (Kuala Lumpur exchange) & CEIC & 3 \\
\hline Nominal effective exchange rate (NEER) & BIS & 2 \\
\hline Real effective exchange rate (REER) & BIS & 2 \\
\hline Exchange rate (per USD) & IMF IFS & 2 \\
\hline Consumer price index (CPI) & CEIC & 3 \\
\hline Producer price index & CEIC & 3 \\
\hline GDP deflator & CEIC & 3 \\
\hline Government spending & Ministry of Finance & 3 \\
\hline Government balance & Ministry of Finance & 3 \\
\hline Revenue (tax) & Ministry of Finance & 3 \\
\hline Government debt & Ministry of Finance & 3 \\
\hline Government debt (domestic) & Ministry of Finance & 3 \\
\hline US real GDP & CEIC & 3 \\
\hline Japan real GDP & CEIC & 3 \\
\hline CRB commodity price index & CRB & 2 \\
\hline VIX & FRED Database & 1 \\
\hline U.S. interest rate (3 month) & CEIC & 1 \\
\hline
\end{tabular}

Data transformation: 1-levels; 2-log level; 3-log difference. 
APPENDIX II. GOVERNMENT SPENDING SHOCKS

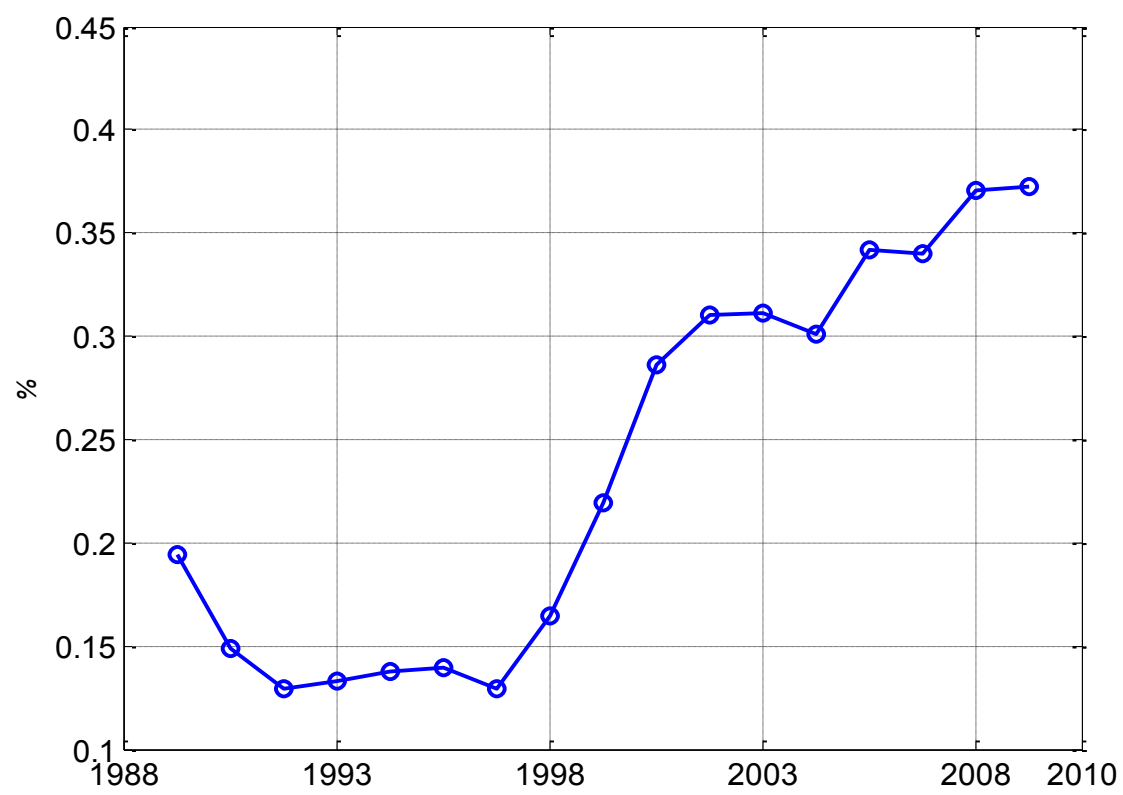

The size of the time-varying second quarter (six-month) shock in government spending

Based on coefficient values drawn in 1993 a 1 percent shock in government spending in quarter one declined to around 0.13. Figure 10 shows, however, that by 2009 the corresponding figure was close to 0.4 . Much of the rise occurred in the years following the Asian financial crisis. 
APPENDIX III. Government SPENding ANd DEbT In MALAYSIA
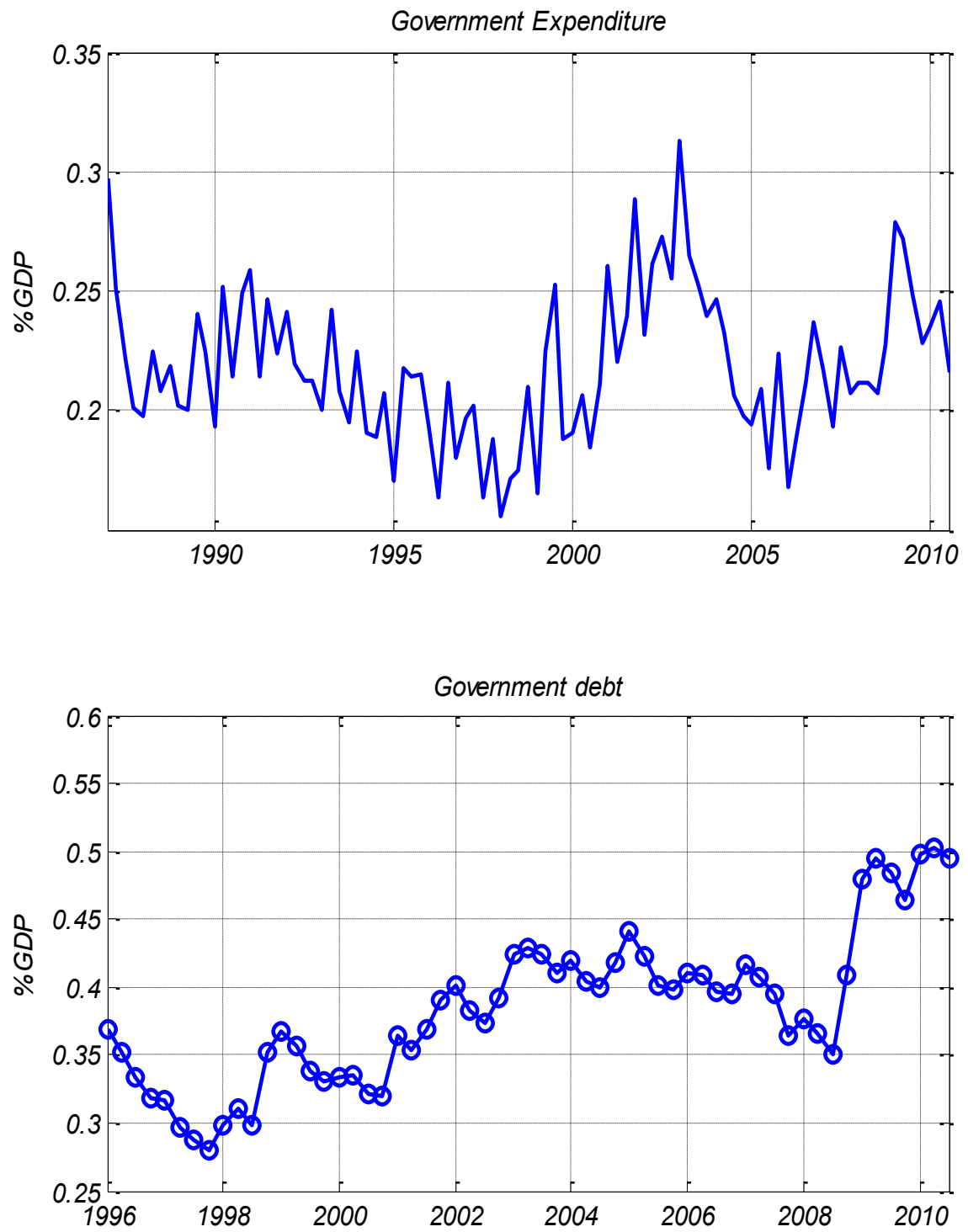

Government expenditure is defined as government consumption plus development expenditure. 


\section{REFERENCES}

Abiad, A., R. Balakrishnan, P.K. Brooks, D. Leigh, and I. Tytell, 2009, "What's the Damage? Medium-Term Output Dynamics After Banking Crises", IMF Working Paper 09/245, (Washington: International Monetary Fund).

Auerbach, A. and Y. Gorodnichenko (2012a), 'Fiscal Multipliers in Recessions and Expansions', in A. Alesina and F. Giavazzi (eds.) Fiscal Policy after the Financial Crisis, forthcoming.

,a and Y. Gorodnichenko (2012b), 'Measuring the Output Responses to Fiscal Policy', American Economic Journal: Economic Policy, 4(2): 1-27.

Abeysinghe, T. and R. Gulasekaran (2004), "Quarterly Real GDP Estimates for China and ASEAN4 with a Forecast Evaluation,” Journal of Forecasting, 23: 431 - 447.

Aghion, P., G-M. Angeletos, A. Banerjee, and K. Manova (2010), "Volatility and Growth: Credit Constraints and the Composition of Investment," Journal of Monetary Economics, 57(3): 246-265.

Alesina, A., F. Campante, and G. Tabellini (2008), "Why is Fiscal Policy often Procyclical," Journal of the European Economic Association, 6(5): 1006 - 1036.

Azrai, E.M. and A.G. Zeufack (2011), "Malaysia: Post-Crisis Growth Prospects Depend on Restoring Fiscal Discipline and Private Sector Confidence", in The Great Recession and Developing Countries: Economic Impact and Growth Prospects, The World Bank, edited by M.K. Nabli.

Bachmann, R. and E. Sims (2011), "Confidence and the Transmission of Government Spending Shocks”, NBER Working Paper No. 17063.

Bai, J. and S. Ng (2002), "Determining the Number of Factors in Approximate Factor Models", Econometrica, 70: 191-222.

Barro, R. and C.J. Redlick (2011) "Macroeconomic Effects from Government Purchases and Taxes”, Quarterly Journal of Economics, 126(1): 51-102.

Baumeister, C., P. Liu and H. Mumtaz (2010), "Changes in the Transmission of Monetary Policy: Evidence from a Time-Varying Factor-Augmented VAR", Bank of England, Working Paper No. 401.

Baxter, M. and R. King (1993), "Fiscal Policy in General Equilibrium”, American Economic 
Review, 83(3): 315-334.

Belviso, F. and F. Milani (2006), "Structural Factor-Augmented VARs (SFAVARs) and the Effects of Monetary Policy", The BE Journal of Macroeconomics, Vol. 6, No. 3 (topics).

Benati, L. (2010), "Evolving Phillips Trade-Off', European Central Bank, Working Paper Series No. 1176.

Bernanke, B.S., J. Boivin and P. Eliasz (2005), "Measuring the Effects of Monetary Policy: A Factor-Augmented Vector Autoregressive (FAVAR)", Quarterly Journal of Economics, 120: 387-422.

Blanchard, O. and L. Summers (1986), "Hysteresis and the European Unemployment Problem", NBER Macroeconomic Annual.

Blanchard, O.J. and R. Perotti (2002), 'An Empirical Characterisation of the Dynamic Effects of Changes in Government Spending and Taxes on Output', Quarterly Journal of Economics, 117(4): 1439-1469.

Burnside, C., M. Eichenbaum and J.D.M. Fisher (2003), "Fiscal Shocks and their Consequences", NBER Working Paper 9772.

Canova, F. and E. Pappa (2006), "The Elusive Costs and the Immaterial Gains of Fiscal Constraints", Journal of Public Economics, 90: 1391 - 1414.

Canova, F. and M. Ciccarelli (2009), "Estimating Multi-Country VAR Models", International Economic Review, 50: 929-959.

Chakraborty, S. and E. Dabla-Norris, "The Quality of Public Investment”, The B.E. Journal of Macroeconomics, 11(1): 1935-1690.

Carter, C.K. and R. Kohn (1994), "On Gibbs Sampling for State Space Models‘, Biometrika, 81: 541-553.

Chari, V.V., P.J. Kehoe and E.R. McGrattan (2005), "A Critique of Structural VARs using Real Business Cycle Theory”, Federal Reserve Bank of Minneapolis Working Paper 631.

Christiano, L., M. Eichenbaum and S. Rebelo (2009), "When is the Government Spending Multiplier Large?”, NBER Working Paper 15394. 
Chung, H. and E. Leeper (2007), "What has Financed Government Debt", NBER Working Paper No. 13425.

Cimadomo, J., S. Hauptmeier and M. Kirchner (2010), "Transmission of Government Spending Shocks in the Euro Area: Time Variation and Driving Forces", European Central Bank Working Paper Series No. 1219.

Cochrane, J. (1994), "Shocks", Carnegie-Rochester Conference Series on Public Policy, 41: 295-364.

Cogley, T. and T.J. Sargent (2005), "Drifts and Volatilities: Monetary Policies and Outcomes in the Post WWII U.S.", Review of Economic Dynamics, 8: 262 - 302.

Corsetti, G., A. Meier, and G. J. Müller (2012), "What Determines Government Spending Multipliers?" IMF Working Paper 12/150, (Washington: International Monetary Fund).

DeLong, B. and L. Summers (2012), "Fiscal Policy in a Depressed Economy”, mimeo

Del Negro, M. (2003), “Comments on 'Drifts and Volatilities” by Cogley and Sargent, Federal Reserve Bank of Atlanta, mimeo.

Devereux, M.B. and D.D. Purvis (1990), "Fiscal Policy and the Real Exchange Rate", European Economic Review, 34(6): 1201 - 1211.

Eggertsson, G. and P. Krugman (2010), "Debt, Deleveraging, and the Liquidity Trap", mimeo.

Eskesen, L. L. (2008), 'The Role for Counter-Cyclical Fiscal Policy in Singapore', IMF Working Paper No. 09/08, (Washington: International Monetary Fund).

Estavão, M. and Samake, I. (2013), 'The Economic Effects of Fiscal Consolidation With Debt Feedback', IMF Working Paper, forthcoming.

Fatas, A. (2000), 'Do Business Cycles Cast Long Shadows? Short-Run Persistence and Economic Growth', Journal of Economic Growth, 5(2): 147 - 162.

Favero, C. and F. Giavazzi (2007), 'Debt and the effects of fiscal policy', NBER Working Paper 12833.

Fernandez-Villerde, J., J. Rubio-Ramirez, T. Sargent, and M. W. Watson (2007), 'ABCs (and Ds) of Understaning VARs', American Economic Review, 97(3): 1021 - 1026. 
Freedman, C., D. Laxton, and M. Kumhof (2008), 'Deflation and Countercyclical Fiscal Policy', unpublished, (Washington: International Monetary Fund).

Galí, J., J. D. Lopéz and J. Vallés (2007), 'Understanding the Effects of Government Spending on Consumption', Journal of the European Economic Association, 5: 227 270.

Giavazzi, F. and M. Pagano (1990), 'Can Severe Fiscal Adjustments be Expansionary', in NBER Macroeconomics Annual, ed. by O. Blanchard and S. Fisher., (Cambridge, MA: MIT Press).

Hansen, L. P., and T. J. Sargent (1991), 'Two Difficulties in Interpreting Vector Autoregressions', in Rational Expectations Econometrics, edited by L. P. Hansen and T. J. Sargent, Westview Press.

Hendry, D. F. (2002), 'Forecast Failure, Expectations Formation and the Lucas Critique', Annales d'Economie et de Statistique, 67/68: 21 - 40.

Hur, S-K. (2007), 'Measuring the Effectiveness of Fiscal Policy in Korea', in ed. by T. Ito and A. Rose Fiscal Policy and Management in East Asia, NBER (EASE), Volume 16. (p. $63-93)$.

Ilzetzki, E. (2011), 'Fiscal Policy and Debt Dynamics in Developing Countries', Policy Research Working Paper 5666, (Washington: The World Bank).

Ilzetzki, E., E. G. Mendoza and C.A. Vegh (2011), 'How Big (Small?) are Fiscal Multipliers‘, IMF Working Paper 11/52, (Washington: International Monetary Fund).

International Monetary Fund (2011), Regional Economic Outlook: Asia and Pacific.

Kim, S., N. Shephard, and S. Chib (1998), 'Stochastic Volatility: Likelihood Inference and Comparison with ARCH Models', The Review of Economic Studies, 65(3), 361- 393.

Kim. S. and N. Roubini (2008), 'Twin deficit or twin divergence?', Journal of International Economics, 74(2): 362 - 383.

Koop, G., H. Pesaran and S. Potter (1996), 'Impulse response analysis in nonlinear multivariate Models', Journal of Econometrics, 74(1): 119 - 147.

(2003), Bayesian Econometrics, John Wiley and Sons.Kwan, Y. K. (2007), 'The Direct Substitution between Government and Private Consumption in 
East Asia', in ed. by T. Ito and A. Rose Fiscal Policy and Management in East Asia, NBER (EASE), Volume 16. (p. 45 - 58).

Leeper. E., T. B. Walker and S-C. S. Yang (2009), 'Government Investment and Fiscal Stimulus in the Short and Long Runs', NBER Working Paper No. 15153.

Mertens, K. and M. O. Ravn (2010), 'Measuring the Impact of Fiscal Policy in the Face of Anticipation: A Structural VAR Approach', Economic Journal, 120(544): 393 - 413.

Monacelli, T. and R. Perotti (2007), 'Fiscal Policy, the Trade Balance and the Real Exchange Rate: Implications for International Risk Sharing', Paper presented at the 8th Jacques Polak Annual Research Conference at the IMF.

Obstfeld, M. and K. Rogoff (1995), 'Exchange Rate Dynamics Redux', Journal of Political Economy, 103(3): 624 - 660.

Pappa, E. (2005), 'New-Keynesian or RBC Transmission? The Effects of Fiscal Shocks in Labour Markets', CEPR Discussion Paper No. 5313.

Park, D., K. Shin and and J. Jongwanich (2009), 'The Decline in Investment in East Asia since the Asian Financial Crisis: An Overview and Empirical Examination', Asian Development Bank, Working Paper Series No. 187.

Perotti, R. (2005), 'Fiscal Policy in Developing Countries: A Framework and Some Questions', The World Bank, Development Research Group, Policy Research Working Paper 4365.

Primiceri, G. E. (2005), 'Time Varying Structural Vector Autoregressions and Monetary Policy', Review of Economic Studies, 72: 821 - 852.

Perotti, R. (2011), 'Expectations and Fiscal Policy: An Empirical Investigation', Technical report, Bocconi

Rafiq, M. S. (2010), 'Fiscal Stance, The Current Account and The Real Exchange Rate: Some Empirical Estimates from a Time-Varying Framework', Structural Change and Economic Dynamics, 21: 276 - 290.

, and A. Zeufack (2012), 'Fiscal Policy and the Growth Cycle: Evidence from Malaysia‘, Policy Research Working Paper No. 5982, (Washington: The World Bank).

Spilimbergo, A. S. Symansky and M. Schindler (2009), 'Fiscal Multipliers', International 
Monetary Fund, IMF Staff Note Position 09/11, (Washington: International Monetary Fund).

Stock, J. H. and M. W. Watson (2008), 'Forecasting in Dynamic Factor Models Subject to Structural Instability‘. In J. Castle and N. Shephard (Eds.), The Methodology and Practice of Econometrics, A Festschrift in Honour of Professor David F. Hendry. Oxford: Oxford University Press.

Tagkalakis, A. (2008), 'The effects of fiscal policy on consumption in recessions and Expansions', Journal of Public Economics, 92: 1486 - 1508.

Turrini, A., W. Roeger, I. and P. Szekely (2011), 'Banking Crises, Output Loss, and Fiscal Policy‘, CESifo Economic Studies, 58 (3): 181-219. 